Carl-Philipp Anke

\title{
Quantitative Analysis of the Reduction of Greenhouse Gas Emissions in the Power Sector
}




\section{IMPRESSUM}

Herausgeber:

Technische Universität Dresden

Fakultät der Wirtschaftswissenschaften

Lehrstuhl für Energiewirtschaft

01062 Dresden

Tel.: $\quad$ +49351463-33297

Fax: $\quad+49351463-39763$

E-Mail: ee2@mailbox.tu-dresden.de

Internet: http://www.ee2.biz

Stand: $\quad 10 / 2021$

Alle Rechte vorbehalten. 


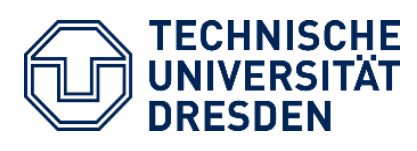

\section{Quantitative Analysis of the Reduction of Greenhouse Gas Emissions in the Power Sector}

\section{Carl-Philipp Anke}

Born on: $21^{\text {st }}$ September 1988 in Dresden

\section{Dissertation}

to achieve the academic degree

Doctor rerum politicarum (Dr. rer. pol.)

Supervisor:

Co-Supervisor:

Date of Submission:

Date of Defense
Prof. Dr. habil. Dominik Möst

Prof. Dr. habil. Alexander Kemnitz

30.09.2020

13.07.2021 


\section{Foreword}

The Paris Agreement set the goal of combating climate change and limiting the rise in global warming to well below $2{ }^{\circ} \mathrm{C}$, preferably to a maximum of $1.5^{\circ} \mathrm{C}$. Greenhouse gas emissions must be reduced rapidly and massively to achieve this goal, and energy systems should become $\mathrm{CO} 2$-neutral in a few decades. The European Union and Germany are striving for a climate-neutral energy system by 2050, respectively 2045 .

To achieve this goal, various political instruments are used, which mainly affect the energy sector. At the European level, the emissions trading system has provided incentives for greenhouse gas reductions in the affected sectors since 2005. In addition, there are European and national targets and funding mechanisms for renewable energies, energy efficiency, etc. The political instruments are often complementary but sometimes also conflicting. Concerning these overlapping instruments, the question arises of what interactions exist between the various instruments and how these instruments interact.

Mr Anke dedicates his dissertation to this relevant question with the title "Quantitative Analysis of the Reduction of Greenhouse Gas Emissions in the Power Sector", and the overarching research question of his work is:

- "How do national and European policy for greenhouse gas mitigation affect the power markets, especially its greenhouse gas emissions, and how do these policies interact?"

To answer this overarching question, which is broken down into further sub-questions in his thesis, $\mathrm{Mr}$ Anke uses quantitative analyses, more precisely fundamental electricity market models. Mr. Anke knows well how to translate policy questions into fundamental models, giving him profound insights into the interplay of different policy instruments. Based on substantial quantitative analyses, he draws political recommendations. The dissertation's contribution lies in analysing the interplay between different policy instruments in the electricity sector and the resulting interactions. In his cumulative thesis, he makes use of five papers, all applying fundamental power market models. He structures his work into the three focus areas:

- Renewable energy sources for electricity production and their effect on European power market and carbon emissions

- Analyses of the coal phase-out and its effects on the valuation of the industry and the EU emission trading system

- Interaction of EU emission trading system with national renewable energy sources deployment strategies 
With that, Mr Anke dedicates his dissertation to a very relevant topic in the energy industry: the interplay of renewables, coal phase-out and emission trading. With his work, he delivers interesting and relevant results for research and industry and political practice. I hope you enjoy reading this informative dissertation!

Prof. Dr. Dominik Möst 


\section{Acknowledgments}

First and foremost, I want to thank my doctoral advisor Prof. Dr. Dominik Möst for supervising my dissertation. Not only did he support the entire process in many discussions and seminars where his insightful remarks provided guidance for the next steps, but also provided academic freedom, which included a safety net that allowed me to always get guidance when needed.

Also, I would like to thank Prof. Dr. Alexander Kemnitz very much for agreeing to review and grade my dissertation. Many thanks to Prof. Dr. Susanne Strahringer and Prof. Dr. Remmer Sassen.

I would also like to thank my colleagues from the Chair of Energy Economics of TU Dresden for inspiration and food for thought over coffee, at the foosball table or in seminars, but especially at the football table. In particular, I would like to thank Constantin Dierstein for answering hundreds of questions about GAMS, Hannes Hobbie for many insights into the academic writing process, and David Schönheit for the motivation his impressive academic achievement has provided for me.

Also, I thank my co-authors (beyond my supervisor and colleagues), Miriam Breitenstein, Prof. Dr. Thomas Walther, Prof. Dr. Duc Khuong Nguyen for the constructive collaborations. Additionally, I want to thank Dr. Robert Kunze, a key project partner, for his support and hard but goal-oriented discussions and feedback.

I am most grateful to my parents for their endless support and love as well as my siblings, Maximilian Anke und Dr. Marie-Luise Anke, those impressive achievements in academia and economy are always an encouragement. Furthermore, I want to thank my friends for their love, support and encouraging conversations before and during the process of this dissertation. Last but not least I would like to express my utmost thankfulness to my wife, Julia, for her endless love and support for whatever idea crosses my mind. 


\section{Summary}

Climate change is one of the pressing issues of our time. In order to limit global warming, the greenhouse gas emissions (GHG) need to be reduced drastically over the next decades in all sectors. A special role is played by the power sector, because it is the one responsible for most GHG emissions and because its costs for decarbonization are rather low. Consequently, national policies aim at reducing GHG emissions by supporting the expansion of renewable energy sources for electricity production (RES) and initiating a coal phase-out (CPO). European policymakers have implemented the EU Emissions Trading Scheme (EU ETS), a mechanism for pricing GHG emissions in the power and industry sector across Europe that incentives carbon mitigation. This dissertation investigates how national and European policies affect the power market and especially its GHG emissions and examines how these policies interact.

This dissertation shows that RES, in addition to the short-term, well-studied, merit order effect, which reduces power wholesale prices, also have long-term effects on electricity markets. The long-term effect describes the impact that RES have on investment decisions into conventional technologies, which are reduced by over $8 \mathrm{GW}$ in Germany. This indicates that the power market adapts to the expansion of RES. With regard to the GHG mitigation of RES, it is shown that currently RES contribute substantially to the mitigation of GHG emissions. Because wind power substitutes coal power, it has a significantly higher potential to avoid GHG emissions than solar power in Germany. Provided wind stays favorable in the future, this portends from a climate perspective that politics should focus on the expansion of wind. It further justifies higher support schemes for wind than solar energy.

The impact of the CPO on the GHG emissions depends strongly on legal implementation. If no further actions are taken, the demand for emission decreases, because existing emitters leave the market and the price drops to $0 \mathrm{EUR} / \mathrm{t}$. The EU ETS loses its incentive effect and the emissions are realized elsewhere since the cap remains the same and is fully exploited. Therefore, alongside the CPO, emission certificates have to be deleted in order to maintain the incentive effect of the EU ETS. Furthermore, the loss in valuation of the German coal power plants depends strongly on the time of the CPO. Given high expected emission prices and the expansion of RES, coal-fired power plants cannot be operated economically advantageously in the long-term. Therefore, no devaluation is expected if power plants are phased out in 2038 or shortly before and hence, those power plants should not receive any compensation.

Additionally, this dissertation shows that the EU ETS is a strong European policy that provides sufficient incentives to meet the European climate targets in 2030 and to realize the necessary expansion of RES. However, if national RES development paths are implemented, this leads to higher overall costs but also very different profitability of RES in each country This is because countries with high ambitions regarding the expansion of RES face self-marginalization effects, which reduces the revenues for RES due to the merit order effect, and increases the level of support needed for them to expand. In contrast, 
countries with low RES ambitions have little or no need of support schemes but benefit from low prices in the EU ETS due to strong RES expansion in countries with high ambitions.

Summarizing, this dissertation demonstrated that both national and European policy contribute to the decarbonization of the European power sector. However, the different policies interact. This can have negative impacts, which indicates that a greater harmonization of policies is necessary. Further research should develop comprehensive policy approaches and discuss possible challenges. 


\section{Table of Contents}

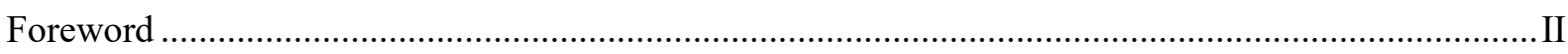

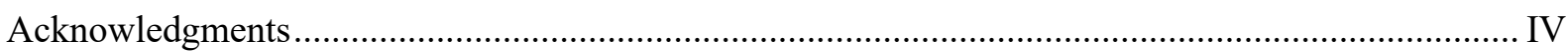

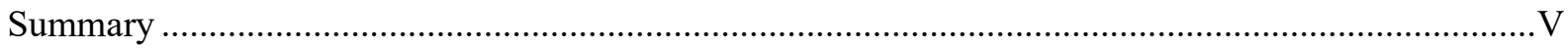

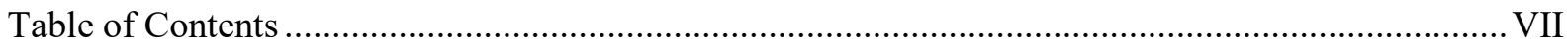

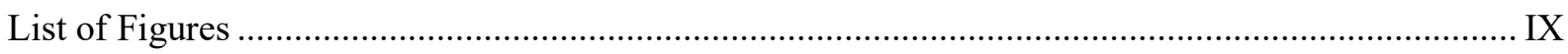

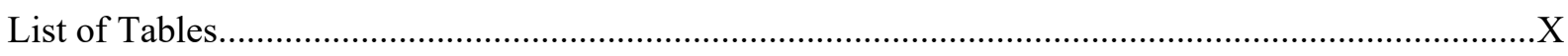

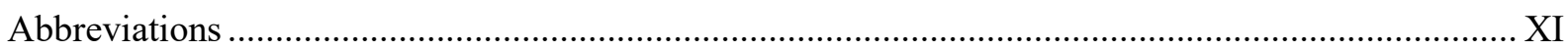

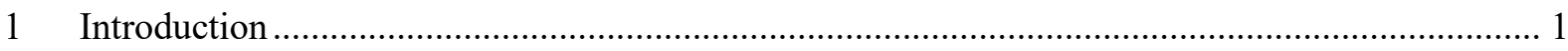

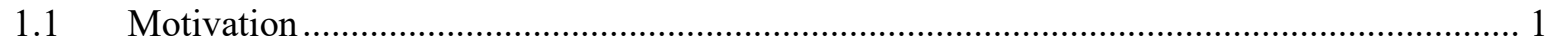

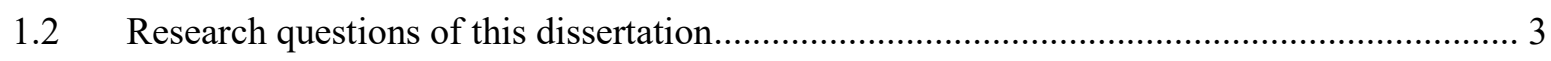

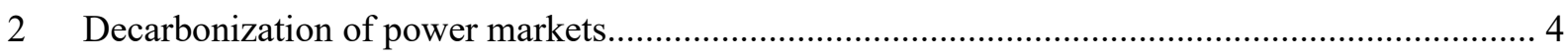

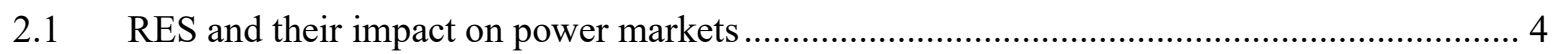

2.2 European Union Emission Trading System ……............................................................. 5

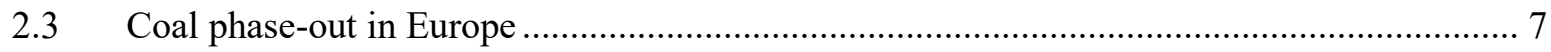

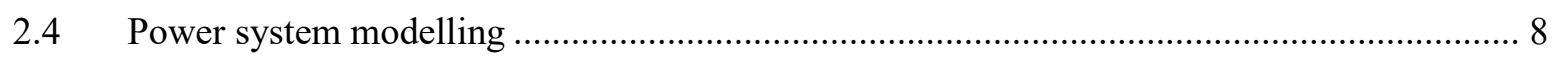

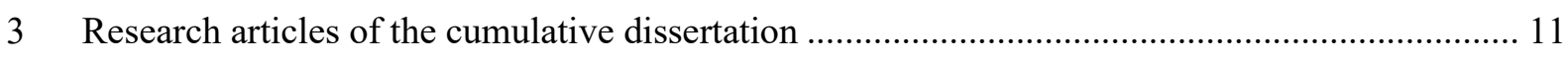

3.1 How RES change the German power system - a counterfactual approach [Paper 1]........... 14

3.2 Calculating the impact of German renewable energy source on the carbon emissions - a

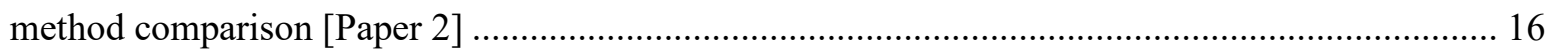

3.3 Coal phase-outs and carbon prices: Interactions between EU emission trading and national carbon mitigation policies [Paper 3]

3.4 Stranded Asset Risk and Political Uncertainty: The Impact of the Coal Phase-out on the German Coal Industry [Paper 4]

3.5 The expansion of RES and the EU ETS - valuable addition or conflicting instruments?

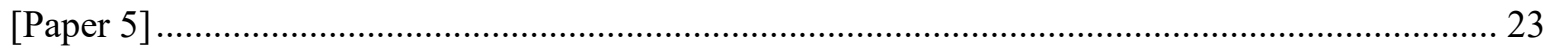

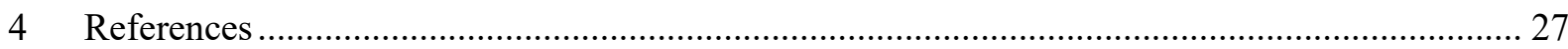

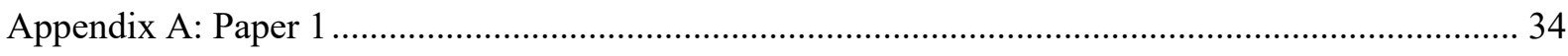

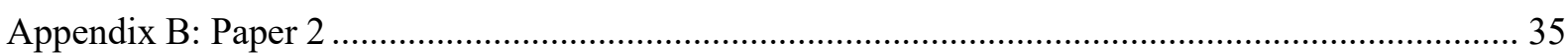




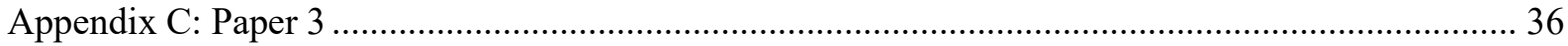

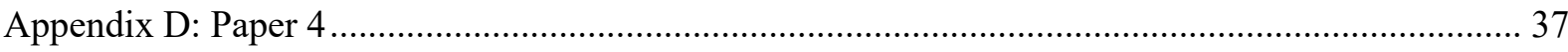

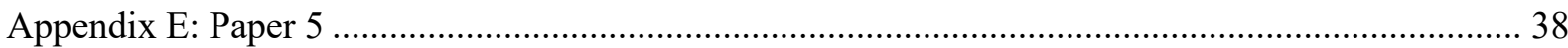




\section{List of Figures}

Figure 1 European greenhouse gas emissions in 2017 per sector (own illustration based on EEA, 2019))

Figure 2 Long-term effects of RES on power generation portfolio (own illustration based on based on Wenders (1976)) 5

Figure 3 Development of the EUA price in EUR / t CO 2 from 2008 to 2019 (own illustration based on Thomson Reuters Datastream, 2020). 6

Figure 4 European phase-out of coal plans (own illustration based on Europe Beyond Coal, 2020) ..... 8

Figure 5 Power market models - Overview (own illustration based on based on Ladwig (2018)) ........ 9

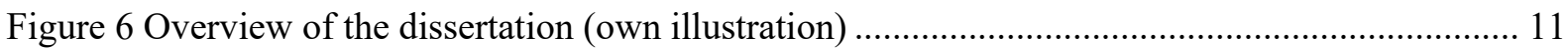

Figure 7: Overview of methodology (own illustration based on Anke (2019)) ................................. 15

Figure 8: Avoided Carbon Emissions in the years in $\mathrm{Mt} \mathrm{CO}_{2}$ (Anke, Schönheit and Möst, no date)... 18 


\section{List of Tables}

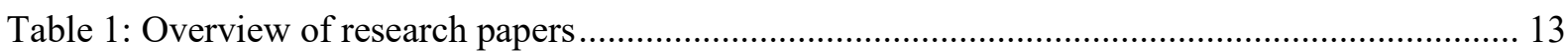

Table 2: Valuation of hard coal and lignite power plants in the different scenarios ............................. 23 


\section{Abbreviations}

$\mathrm{CPO}$

$\mathrm{CO}_{2}$

DCAS

DIS

EEG

ECO

EPAS

ELTRAMOD

EU

EU ETS

EUA

GHG

FC

ICA

IAEE

INDC

MCAS

MSR

NaPoM

NPV

PEE

RES

VC

VHB-JOURQUAL
Coal Phase-Out

Carbon Dioxide

Delaying Climate Action Scenario

Dispatch Model

Renewable Energy Sources Act

Econometric Methods

Enforcing Paris Agreement Scenario

Electricity Transshipment Model

European Union

European Union Emission Trading System

European Union Allowances

Greenhouse Gases

Fixed Costs

International Climate Action

International Association for Energy Economics

Indented Nationally Determined Contributions

Maintaining Climate Action Scenario

Market Stability Reserve

National Policy Measures

Net Present Value

Primary Energy Equivalent

Renewable Energies Sources for Electricity Production

Variable Costs

Verband der Hochschullehrer für Betriebswirtschaft Zeitschriftenrating 3 (Journal rating of German Academic Association of Business Research 


\section{Introduction}

\subsection{Motivation}

Global warming, one of the most pressing problems of our time, is most likely caused by the high concentrations of greenhouse gases $(\mathrm{GHG})$ such as carbon dioxide $\left(\mathrm{CO}_{2}\right)$ and methane ${ }^{1}$. More than half of the temperature increase is likely to be attributed to anthropogenic effects, especially the combustion of fossil fuels (IPCC, 2015). Current scenarios with a temperature increase above $1.5{ }^{\circ} \mathrm{C}$ suggest dramatic consequences for the environment and the living conditions of millions of people (IPCC, 2018).

To limit anthropogenic climate change, the international community agreed on the United Nations Framework Convention on Climate Change in 1992 and ratified it in 1994. It was the first international treaty that classifies climate change as a serious threat (United Nations, 1992). With the Kyoto Protocol of 1997, countries committed themselves for the first time to reduce their GHG emissions (UN, 1998). In the Paris Climate Convention in 2015, the international community of states agreed to limit climate change to $2{ }^{\circ} \mathrm{C}$, preferably below (UNFCCC, 2015). Against this background it is safe to assume that an imperative need for action to reduce the GHG emissions exists and that policy makers worldwide are aware of it.

In order to limit global warming to $2{ }^{\circ} \mathrm{C}$ or below, the overall greenhouse gas emissions need to be reduced to zero and the world must become carbon neutral until 2050, and extract GHG from the atmosphere after 2050 (IPCC, 2018). In order to achieve this ambitious goal, the participating countries have agreed to Indented Nationally Determined Contributions (INDC), which determine the emission reduction path for the next years. With regard to the different economic strengths and the higher perperson emissions of western countries, these countries have higher INDC and thus must reduce their carbon emissions much more in the short-term (IPCC, 2018). For instance, the European Union (EU) aims to reduce its carbon emissions by $40 \%$ compared to 1990 until 2030 (EC, 2019a). The strong necessity to decrease carbon emissions, as well as the corresponding, strong climate policies, which will be described later on, make the EU and especially Germany an interesting case to analyze.

Across different sectors, the energy sector plays a central role for reaching the climate goals. The strong decarbonization means that all sectors are affected and must reduce their carbon foot print in order to meet the ambitious climate goals (IPCC, 2018). But on the one hand, energy is the sector with the highest carbon emissions, since it accounts for $26 \%$ of the total carbon emissions in Europe (see Figure 1) (EEA, 2019). On the other hand, it is a sector with low carbon mitigation costs (Bartholdsen et al., 2019).

\footnotetext{
${ }^{1}$ In the following, greenhouse gas emission are also referred to as carbon emissions or $\mathrm{CO}_{2}$ emissions. $\mathrm{CO}_{2}$ represent about $75 \%$ of the GHG emission in 2010 and is comparative value for the damaging effect of GHGs on the climate (IPCC, 2014).
} 
Therefore, energy policy makers have focused on the environmental protection part in the triangle of objectives of energy policy. The focus here lies especially on the reduction of GHG emissions.

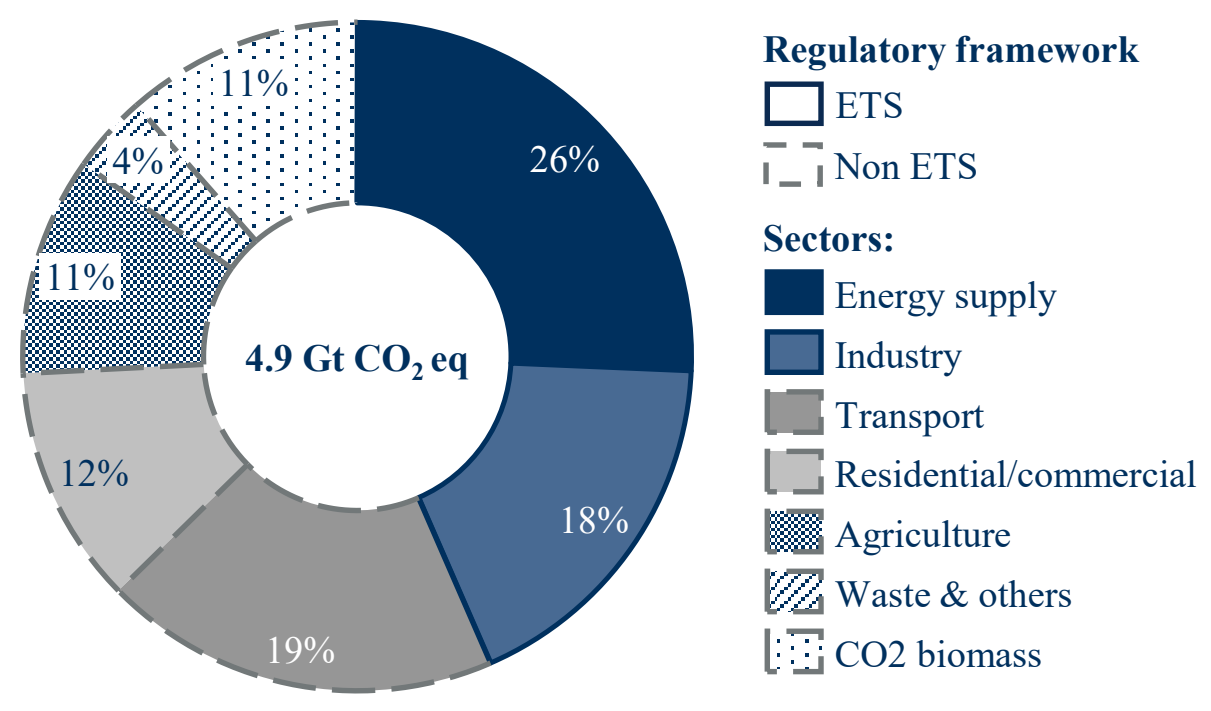

Figure 1 European greenhouse gas emissions in 2017 per sector (own illustration based on EEA, 2019))

To this end, various policies have been adopted in Europe at both national and European level. These measures affect in particular the value-adding stage of electricity generation, as this is responsible for all direct $\mathrm{CO}_{2}$ emissions during operation. At the European level, the European Union Emission Trading System (EU ETS) was introduced in 2005 (EU, 2004) to mitigate $\mathrm{CO}_{2}$ emissions. The EU ETS is a cap and trade system for $\mathrm{CO}_{2}$ emissions that was introduced as a central climate protection element of the EU. It limits the total amount of carbon emissions in the participating industries (energy, chemicals, etc.) and allows the European Union Allowances (EUA), the certificates required for emitting $\mathrm{CO}_{2}$, to be traded among the market participants. This introduces a price for emissions and allows the abatement of carbon emissions to take place where the costs are lowest (Rickels et al., 2007).

In addition to the transnational EU ETS, many countries expand their RES capacities, which can produce electricity without $\mathrm{CO}_{2}$ emissions. Since the RES initially had high levelized cost of energy, the expansion was supported by government support schemes (IRENA, 2016; Mezösi, Szabó and Szabó, 2018). Germany, for example, introduced the Renewable Energy Sources Act (EEG) in 2000, promoting the expansion of RES. The feed-in of renewable energies increased from approximately $36 \mathrm{TWh}$ in 2000 to 225 TWh in 2018, contributing to about $38 \%$ of the electricity demand (BMWi, 2019b). Despite this massive expansion of renewable energy in Germany, $\mathrm{CO}_{2}$ emissions of the energy sector only decreased

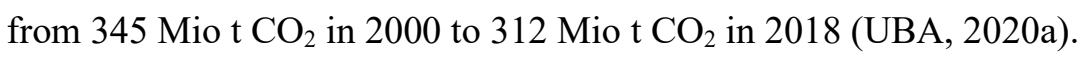

In view of the slow decrease in $\mathrm{CO}_{2}$ emissions in the power sector, many countries have decided to take further national measures to reduce their carbon footprint. These policies include in particular the phaseout of $\mathrm{CO}_{2}$ intensive coal-fired power generation to further expand renewable energies. These national measures are likely to reduce the national carbon emissions and, hence, lower the demand for EUAs. 
This would be expected to cause a drop in EUA prices and thus a lower incentive to reduce carbon emissions and therefore, in the worst case, to a net-mitigation effect of zero as well. This market behavior is called waterbed effect (Perino, 2018; Rosendahl, 2019). In theory this can be overcome if sufficient EUAs are deleted, which will be possible after 2023. This was introduced in directive 2018/310 of EU that reforms the EU ETS (EU, 2018).

Against the background of the necessity to decarbonize the power system, and against ongoing policy development, many research questions arise, of which some the dissertation at hand addresses.

\subsection{Research questions of this dissertation}

The general subject of the dissertation - Quantitative Analysis for the Reduction of Greenhouse Gas Emissions in the Power Sector - concerns policies for the emission mitigation and their effect on greenhouse gas emissions. The central research question analysed into this dissertation is:

How do national and European policy for greenhouse gas mitigation affect the power markets, especially its greenhouse gas emissions, and how do these policies interact?

In order to answer the complex research question it is further subdivided in the following questions:

- How do RES affect the development of the German power market?

- What are the advantages and disadvantages of existing methods for calculating avoided emissions?

- How do different renewable energies influence the $\mathrm{CO}_{2}$ emissions of the power supply?

- How does the coal phase-out affect the functioning of the EU ETS?

- Which impact will the coal phase-out have on the valuation of the assets concerned and what compensation will be paid?

- How do national RES targets affect the EU ETS and the economic feasibility of RES?

On the basis of quantitative analyses that apply fundamental power market models, the interrelationships of carbon mitigation measures within the power market are investigated, and corresponding policy recommendations are derived. The contribution of the dissertation stems, in particular, from analyzing the interplay of the various climate policies and the arising interactions. In addition, the impact of individual policies on the power market and its carbon emissions are analyzed.

This dissertation is structured as follows: Chapter 2 introduces the national and European measures for carbon emission reduction in the power sector and basics of power market modelling. Chapter 3 presents the papers of this dissertation and their contribution to the literature. 


\section{Decarbonization of power markets}

This chapter introduces the theoretical background of the decarbonization of power markets, which is analyzed in this dissertation. The focus lies on national and European policies for carbon mitigation that will be quantitatively analyzed in the papers of this dissertation. The different policies are connected to each other. In order to ensure comprehensibility of their interactions, which are examined in the papers, each policy is explained in detail.

Chapter 2.1 provides an overview of the short and long-term effects of RES on the power market. Afterwards, Chapter 2.2. presents the EU ETS and its instruments. An overview of the European coal phase-out is provided in chapter 2.3. In the end, Chapter 2.4 introduces power market models, which constitute the methodological foundation of the dissertation.

\subsection{RES and their impact on power markets}

RES have other characteristics than conventional power plants, since their variable costs are (almost) zero in contrast to their high fixed costs. Hence, they reduce the residual load ${ }^{2}$ that needs to be covered by conventional generation. This leads to lower market prices, since conventional power plants shift to the right in the merit order. Therefore, a power plant with lower generation cost sets the power price. This effect is called merit-order effect in the short-term (Diekmann et al., 2007; Weigt, 2009; Cludius et al., 2014; Praktiknjo and Erdmann, 2016; among others). This secures that RES produce power whenever possible but can in the long run, when more and more RES are installed, lead to a selfmarginalization: RES reduce power prices (merit-order), which make it more difficult for them to recover their fix costs.

Additionally, RES impact the capacity development of conventional power plants, since they reduce the residual load. According to peak load theory, the reduced residual load will lead to a different power generation portfolio (Wenders, 1976). This is demonstrated by Figure 2. It shows the load and residual load at the top, and the screening curves at the bottom. The screening curves are the cost functions of the different power plant technologies, which include fixed (FC) as well as variable costs (VC). Fixed cost correspond to the intersections with the y-axis, and variable costs to the slopes of the curves.

From the intersections of the curves the optimal technology can be derived for a certain amount of full load hours. When extending these intersections up to the residual load, the new intersections show the optimal capacities for each technology. If the power plant portfolio changes and, for instance, more coal-

\footnotetext{
${ }^{2}$ Residual load is defined as the total demand for power minus the power generation from RES, hence it is the share of the demand that needs to be covered by conventional power plants.
} 
fired capacities would be available in a scenario without RES, then it is likely that RES avoid a different amount of $\mathrm{CO}_{2}$.

The impact of RES on the power market is analyzed in first two papers. Paper 1 examines in particular how the expansion of RES affects the conventional power plant park. The second paper analyzes the contribution of RES to $\mathrm{CO}_{2}$ avoidance, and which methods are suitable for the calculation of this mitigation effect.

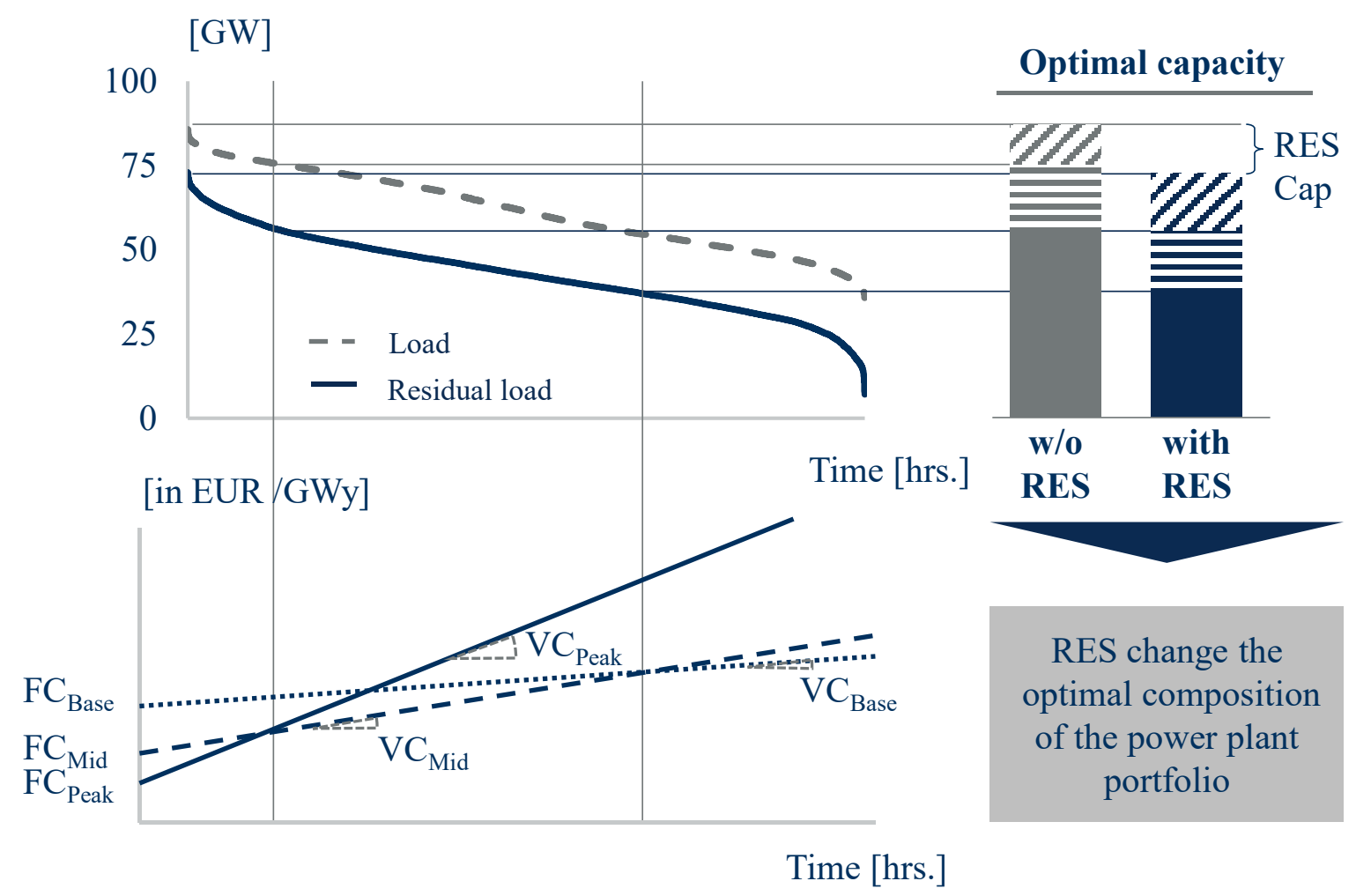

Figure 2 Long-term effects of RES on power generation portfolio (own illustration based on based on Wenders (1976))

\subsection{European Union Emission Trading System}

The EU ETS is Europe's key policy for the decarbonisation of the power and industry sector. Introduced in 2005, it provides a price for carbon emissions in Europe. The EU ETS is a cap and trade system. Parties under the regulation of the EU ETS must have EUA for their carbon emissions. The EUAs are mainly auctioned or freely allocated and can be traded amongst the market participants. The number of allocated EUAs per year is limited and continuously reduced to meet the European climate targets (Böhringer et al., 2016). The quantity limitation at European level is intended to ensure that cost efficient emission reduction measures are implemented irrespective of the country. All sectors that are not regulated in EU ETS (agriculture, transport, etc.) are summarized as Non ETS. Reduction targets and policy measures for these sectors are mainly on a national level. 
Among the sectors regulated under the ETS, the power sector holds a central role. On the hand it is the sector responsible for the major share of the emissions (EEA, 2019). On the other hand it has lower mitigation costs than the industry under the regulation of the EU ETS (Hillemacher and Fichtner, 2012). Hence the power sector drives the fundamental market development of the EU ETS.

For most of the time the EUA price has been rather low (see Figure 4) and its ability to provide price signals for carbon mitigation was put into question (Chaton, Creti and Peluchon, 2015). In order to improve the EU ETS two major reforms have been implemented: Backloading and the Market Stability Reserve (MSR). Backloading reduced the auction volumes from 2014 to 2019 and allowed the certificates to enter the market only with a time lag. The MSR introduces a tool for the management of the liquidity of the EU ETS. It reduces the number of certificates auctioned when the number of certificates in market becomes too high (upper threshold). The non-auctioned EUAs, as well as the EUAs form Backloading, are stored in the MSR. The stored EUAs re-enter the market when the number of certificates in the market becomes too low. The reduction is limited to $12 \%$ of the excess certificates per year. (Graichen and Matthes, 2018)

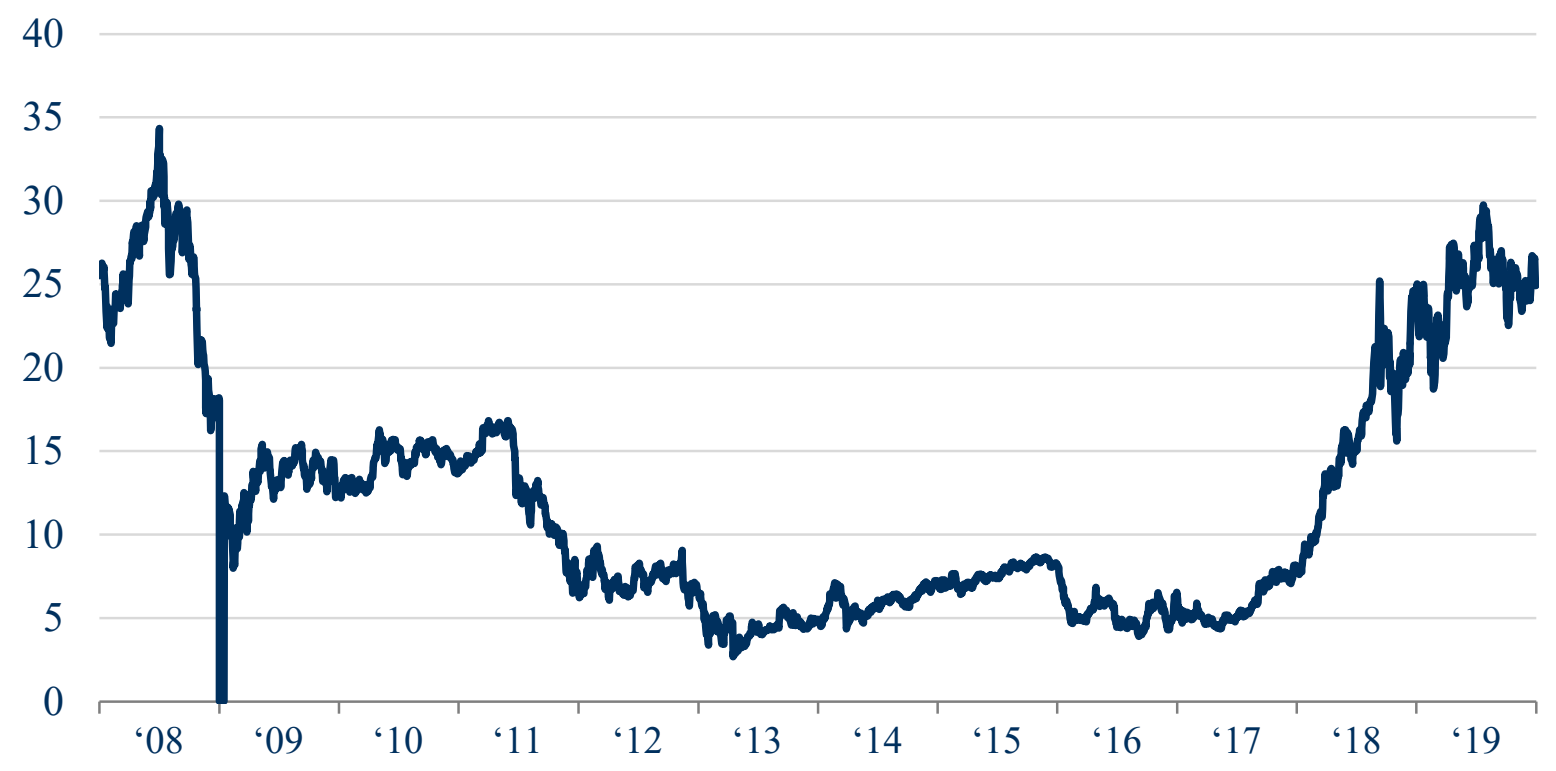

Figure 3 Development of the EUA price in EUR / $\mathbf{C} \mathrm{CO}_{2}$ from 2008 to 2019 (own illustration based on Thomson Reuters Datastream, 2020)

The EU ETS links all participating countries, as it provides a central price signal for the mitigation of carbon emissions. However since the cap is fixed, the carbon price drops if countries reduce their carbon emissions. Therefore, it reduces the incentives for carbon mitigation for all other countries. In the end emissions stay at the same level and only the distribution changes due to the waterbed effect. The MSR is meant to reduce this effect because it can absorb the "saved emissions". However, this only works in 
the long-run, and if the carbon price does not react to the short-term fundamentals ${ }^{3}$. A further way to reduce the waterbed effect is the direct cancellation of EUAs, for instance when power plants are phased out.

The EU ETS and especially carbon prices play a crucial role in all papers of this dissertation. The interaction with national carbon mitigation policies is analyzed in paper 3 and 5 .

\subsection{Coal phase-out in Europe}

Power generation from coal is one of the oldest technologies for power generation. It was the foundation of the development of the power sector all over the world because of the simplicity of the technology and the good availability of resources in the past. The great disadvantage of coal is the high emission factor, which means that - per unit of coal - a lot of carbon is emitted. Furthermore, the power plant efficiency is limited to about $50 \%$ for technical reasons, while natural gas fired plants can reach over 60\% (Löschel et al., 2020). Together with a much lower emission factor this makes natural gas fired power plants the favorable option for the low emission power system (UBA, 2016) ${ }^{4}$. Due to past cost advantages however, generation from coal is responsible for about $35 \%$ of the total power generation, but $77 \%$ of the German carbon emissions in the power sector (UBA, 2020b, 2020c). Therefore many European governments decided to phase-out coal (see Figure 4).

The political decision to phase-out coal leads to a loss in the valuation of coal fired power plants, since they cannot further participate in the market anymore and hence cannot generate cash flow, which leads to a loss in valuation. For this reason, coal fried power plants are called stranded assets (Jewell et al., 2019). Here, the legal question arises as to whether governments are liable for the valuation loss and have to compensate the power plant owners.

The coal phase-out as a national policy is put into focus in paper 3 and 4. Paper 3 analyzes its impact on the EU ETS, while the fourth paper investigates the impact of CPO on the valuation of the coal industry.

\footnotetext{
${ }^{3}$ This means that the market price does not react to short-term changes in demand and hence the emissions stay at the same level.

${ }^{4}$ New coal fired power plants emit about $750 \mathrm{~kg} \mathrm{CO}_{2} / \mathrm{MWh}$ while highly efficient natural gas-fired power plants only emit $320 \mathrm{~kg} \mathrm{CO} / \mathrm{MWh}$.
} 
Coal phase out announced

Coal phase out under discussion

No coal phase out discussions

No coal in electricity mix

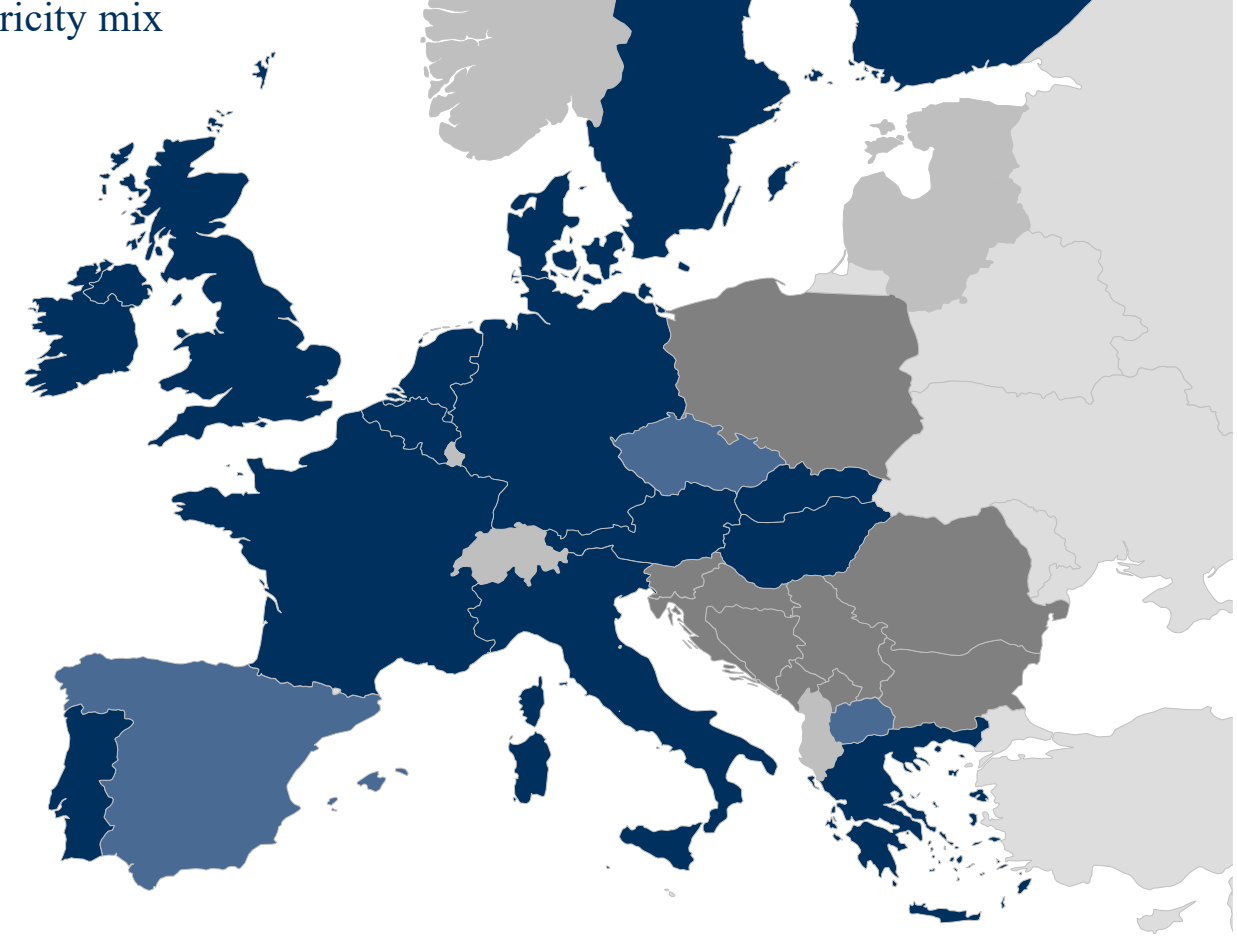

Figure 4 European phase-out of coal plans (own illustration based on Europe Beyond Coal, 2020)

\subsection{Power system modelling}

Power market models provide a simplified representation of reality and are used to answer complex questions regarding power markets. Depending on the application, there are different modeling approaches, and the choice of the approach depends on the observation period, the object of observation, etc. (Möst and Fichtner, 2009). For long-term analyses in markets with perfect competition, optimization models are particularly suitable. This is because they represent the techno-economic relationships particularly well (Ventosa et al., 2005). For Germany, Möst and Genoese (2009) show that there is no exercise of market power, and Graf and Wozabal (2013) find that the German power market has a competitive environment. Optimization models belong to the class of bottom-up models, which put particular emphasis on technical aspects and restrictions, and are therefore particularly suited to analyze the transformation processes of a system. In contrast, top-down models are used for cross-sectorial analyses, because interactions between sectors are put into focus. Production conditions are usually being represented by elasticity, but often remain constant. This means that changes within the energy system cannot be represented (Möst and Fichtner, 2009). 
In this dissertation the Electricity Transshipment Model (ELTRAMOD) is applied. It was developed at the Chair of Energy Economics of the TU Dresden and has been adapted to answer the specific research questions. A general model description can be found in Schubert (2016) and Ladwig (2018). ELTRAMOD is a classic bottom-up model, in which the target function minimizes the costs of the supply of a given load. Furthermore, technical restrictions regarding the ramping of power plants or dispatch of combined heat and power plants are considered in constraints. These also consider fluctuations of RES and the specifics of hydro-power plants. In order to improve the performance of ELTRAMOD it can be subdivided into two modules; ELTRAMOD INVEST that focuses on the general expansion problem and ELTRAMOD DISPATCH, which investigates the power plant dispatch.

The input parameters for a power market optimization model are the fundamental data for the power generation, the demand, and the trade infrastructure (see Figure 5). Based on this information the mathematical model calculates the cost-optimal dispatch of the power plants and, if needed, the additional investments into new generation capacities.

\begin{tabular}{|l|}
\hline \multicolumn{1}{|c|}{ Input } \\
\hline Generation \\
\hline - Fuel prices \\
- $\mathrm{CO}_{2}$-prices \\
- Generation parameter \\
- Generation capacities \\
Hourly RES feed in \\
profiles \\
\hline Demand \\
\hline - Annual power demand \\
\hline Hourly load curve \\
\hline Infrastructure \\
\hline - $\begin{array}{l}\text { Copper plate with a } \\
\text { market zone } \\
\text { - Transnational trade } \\
\text { limited via NTC } \\
\text { (hourly values) }\end{array}$ \\
\hline
\end{tabular}
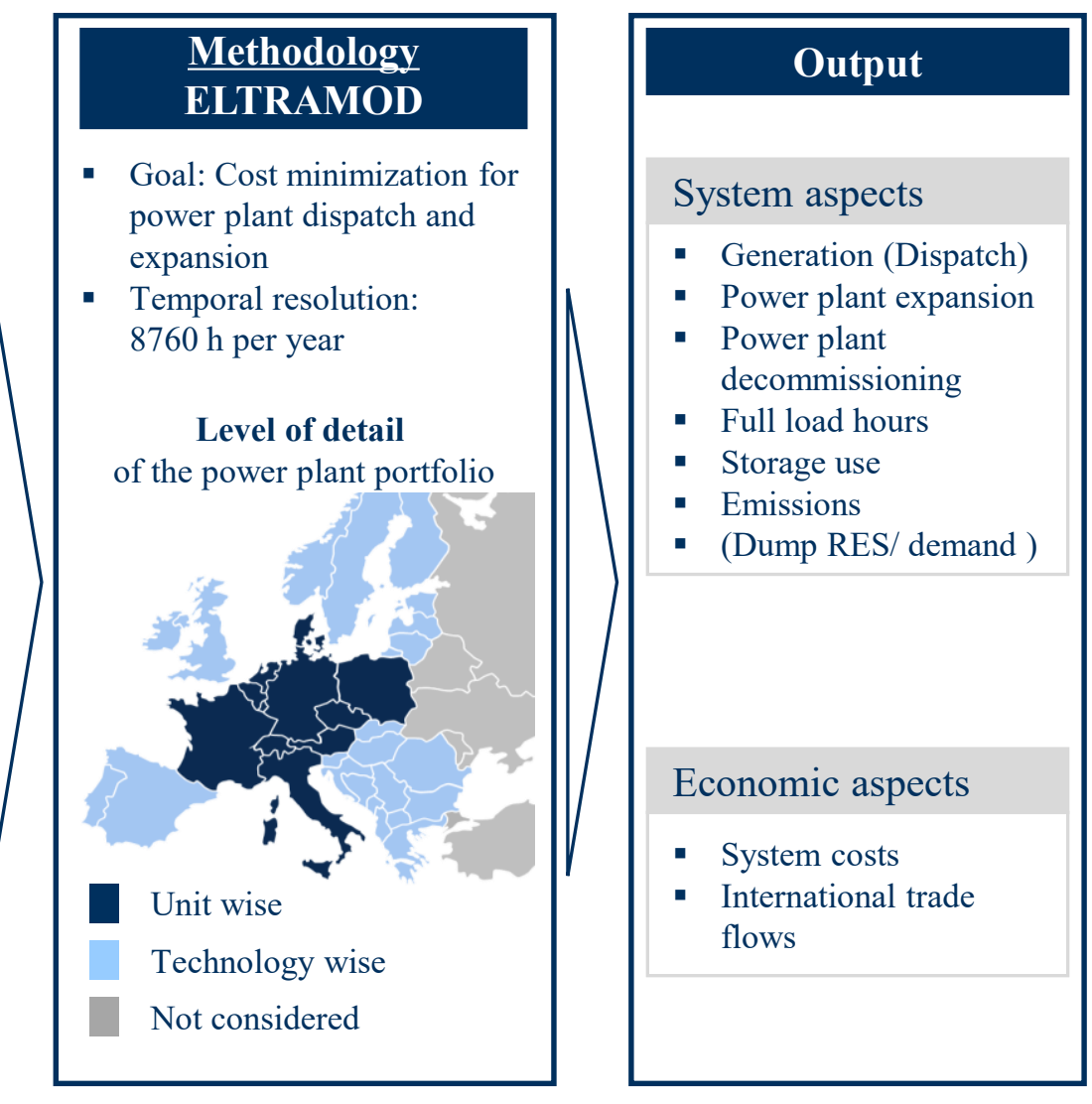

Figure 5 Power market models - Overview (own illustration based on based on Ladwig (2018))

Power market optimization models provide the methodical framework for analysis of power systems. These are applied to scenarios, which summarize a set of internally consistent and coherent assumptions representing potential future developments (IPCC, 2018). These scenarios are the basis for evaluating 
the impact of a policy, which is done via scenario comparisons: In one scenario the policy is implemented, and in a second one, it is not.

Counterfactuals constitute a special type of scenario. Instead of the future, an alternative present is developed, in which a policy or event is not considered that has affected the current reality (Ferraro, 2009). The goal is to develop a counterfactual reality which differs from reality only in one aspect and hence provides a basis for the evaluation of a specific assumption/policy. For example, a counterfactual scenario could describe the development of the German power system without RES (as it is done in the first paper). Thus, it models an alternative (counterfactual) development path of the German power system described, which would have taken place parallel to reality if the expansion of RES had not been realized.

All papers are based on power market models and apply scenarios. In all papers, except paper 4 , ELTRAMOD is implemented to investigate the specific research question. Paper 4 applies a simplified fundamental power market model. 


\section{Research articles of the cumulative dissertation}

The dissertation consists of 5 papers dealing with quantitative analyses of emissions reduction in the power sector (Figure 6). The first two papers focus on RES and their impact on power markets and carbon emissions. The third and fourth paper investigate the CPO and its impact on the EU ETS and the valuation of the coal industry. The fifth paper examines the interaction of national RES deployment strategies with the EU ETS. All five papers apply fundamental power market models to answer the specific research questions.

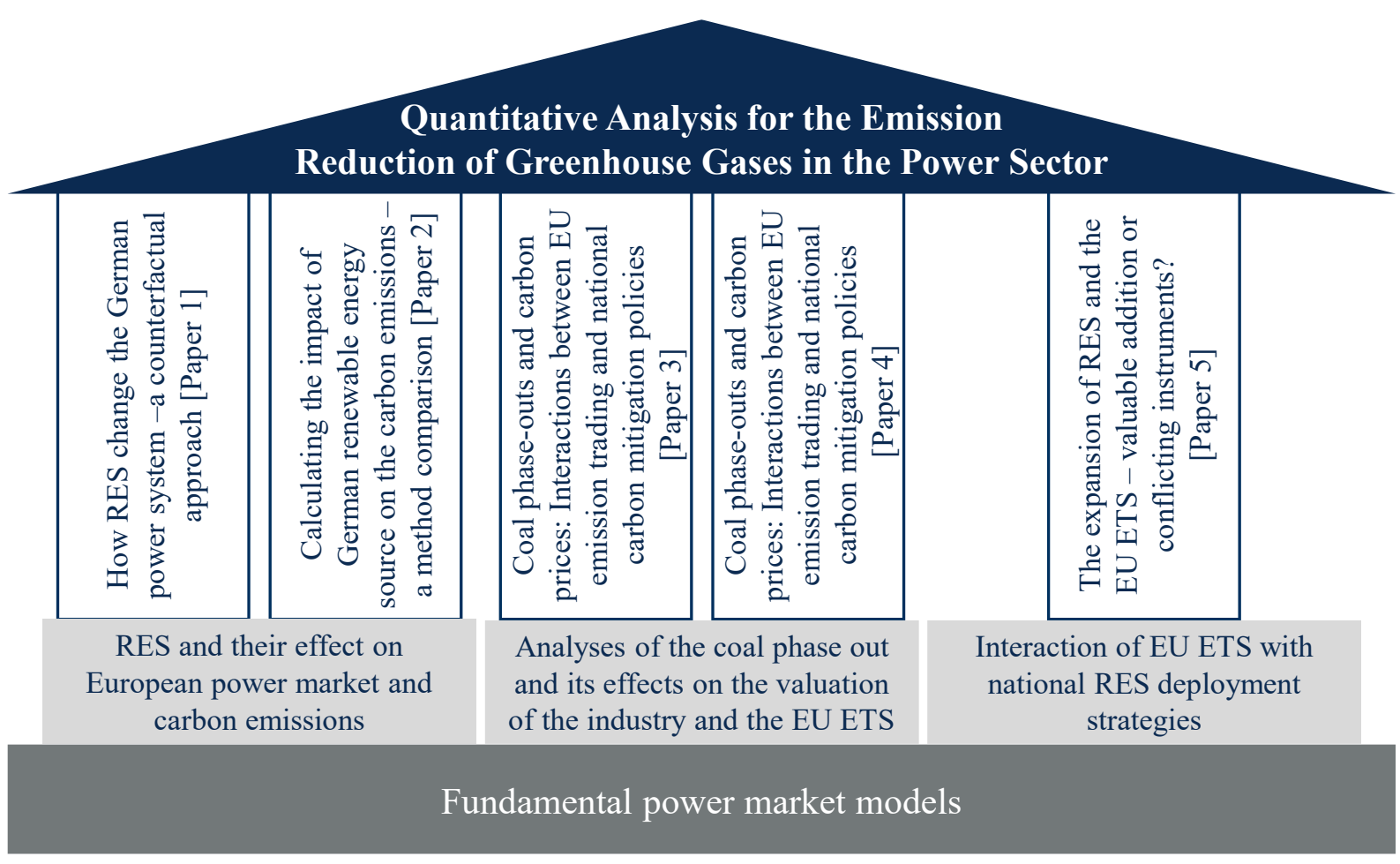

Figure 6 Overview of the dissertation (own illustration)

The first paper develops a counterfactual scenario in which Germany has no RES. Based on this counterfactual scenario the counterfactual German power generation portfolio is calculated using ELTRAMOD. The differences between the real and counterfactual power plant portfolio correspond to the long-term effects of RES. The counterfactual power plant portfolio is used in a scenario comparison to investigate the effects of the German RES on the European power market.

The counterfactual power generation portfolio is an important input for one of the methods applied in the second paper. There, three types of approaches identified by Holttinen et al. (2015) to calculate the $\mathrm{CO}_{2}$ avoidance are compared qualitatively and quantitatively. All methods are implemented for Germany for the years 2016 to 2017. Unlike earlier approaches, this allows for a valid comparison of their results, since the methods are applied to the same regional area and the same time. This allows for a better understanding of both methodological and technological effects on long-term aspects of RES. 
Summarizing, papers one and two contribute to the literature by enhancing the understanding of how RES affect the power market and its carbon emissions. Furthermore, the long-term effects of RES are analyzed. Both support policy makers in their decisions on which RES technologies should be expanded further.

In the third paper, the interaction of national carbon mitigation policies with the EU ETS is examined. Based on a scenario comparison, the effect of the coal phase-out on the EUA prices is calculated. Additionally, a method for calculating the amount of EUAs to be cancelled is proposed. Based on these calculations, the number of EUAs that need to be canceled to secure the capability of EU ETS to provide sufficient price signals is then determined. Additionally, the effect of different RES deployment strategies is analyzed.

Furthermore, the coal phase-out does not only affect the EU ETS, it also questions the whole coal industry - and with it, its entire valuation. The loss in valuation can be a basis for the compensation payments the industry should receive. Based on two phase-out scenarios for 2030 and 2038 the fourth paper calculates the financial, political and environmental impacts of the coal phase-out.

Papers 3 and 4 expand the literature by exploring the interaction of EU ETS with the national coal phaseouts across Europe. In addition, the paper contributes to the discussion of possible compensations by adding a calculation on the loss of valuation of the coal industry due to the CPO.

The coal phase-out is an import step for reaching the European climate targets by themselves, but it also interacts through the EU ETS with the expansion of RES discussed above. So far, RES expansion is strongly driven by governmental support schemes (Ragwitz and Steinhilber, 2014). But given the coal phase-out, the power prices are likely to increase due to less mid and base load capacities. Additionally, the investments for new RES are likely to decrease further due to scaling effects (IRENA, 2016). Both effects will increase the economic feasibility of RES. In the fifth paper, the effects of national RES deployment strategies are analyzed. In particular, they are compared with a scenario with international coordination, where RES are developed based on an optimization approach that aims at reducing the overall system costs.

This last paper adds to the literature by elaborating the potential of the EU ETS in relation to RES. In addition, a scenario comparison analyzes the impact of the national development strategies and their distribution effects.

Table 1 presents an overview of the articles that are included in this cumulative dissertation. Furthermore, it shows the authors that worked on the articles and the journals in which they were published. 
Table 1: Overview of research papers

\begin{tabular}{|c|c|c|c|c|}
\hline Article & Title & Authors & Status & Journal \\
\hline 1 & $\begin{array}{l}\text { How RES change the } \\
\text { German power system } \\
\text { - a counterfactual } \\
\text { approach }\end{array}$ & Anke, C.-P. & Published & $\begin{array}{l}\text { Zeitschrift für } \\
\text { Energiewirtschaft } \\
\text { VHB-JOURQUAL: C } \\
\text { Impact Factor: } 0.62\end{array}$ \\
\hline 2 & $\begin{array}{l}\text { Calculating the impact } \\
\text { of German renewable } \\
\text { energy source on the } \\
\text { carbon emissions - a } \\
\text { method comparison }\end{array}$ & $\begin{array}{l}\text { Anke, C.-P.; } \\
\text { Schönheit, D.; } \\
\text { Möst, D. }\end{array}$ & Published & $\begin{array}{l}\text { Zeitschrift für } \\
\text { Energiewirtschaft } \\
\text { VHB-JOURQUAL: C } \\
\text { Impact Factor: } 0.62\end{array}$ \\
\hline 3 & $\begin{array}{l}\text { Coal phase-outs and } \\
\text { carbon prices: } \\
\text { Interactions between } \\
\text { EU emission trading } \\
\text { and national carbon } \\
\text { mitigation policies }\end{array}$ & $\begin{array}{l}\text { Anke, C.-P.; } \\
\text { Hobbie, H.; } \\
\text { Schreiber, S.; } \\
\text { Möst, D. }\end{array}$ & Published & $\begin{array}{l}\text { Energy Policy } \\
\text { VHB-JOURQUAL: B } \\
\text { Impact Factor: } 4.88\end{array}$ \\
\hline 4 & $\begin{array}{l}\text { Stranded Asset Risk } \\
\text { and Political } \\
\text { Uncertainty: The } \\
\text { Impact of the Coal } \\
\text { Phase-out on the } \\
\text { German Coal Industry }\end{array}$ & $\begin{array}{l}\text { Breitenstein, M.; } \\
\text { Anke, C.-P.; } \\
\text { Nguyen, D. K.; } \\
\text { Walther, T. }\end{array}$ & Accepted & $\begin{array}{l}\text { The Energy Journal }{ }^{5} \\
\text { VHB-JOURQUAL: not } \\
\text { ranked } \\
\text { Impact Factor: } 2.46\end{array}$ \\
\hline 5 & $\begin{array}{l}\text { The expansion of RES } \\
\text { and the EU ETS - } \\
\text { valuable addition or } \\
\text { conflicting } \\
\text { instruments? }\end{array}$ & $\begin{array}{l}\text { Anke, C.-P.; } \\
\text { Möst, D. }\end{array}$ & Published & $\begin{array}{l}\text { Energy Policy } \\
\text { VHB-JOURQUAL: B } \\
\text { Impact Factor: } 4.88\end{array}$ \\
\hline
\end{tabular}

(Own table)

\footnotetext{
${ }^{5}$ The Energy Journal is a reputable and recognized journal of the International Association for Energy Economics (IAEE), It the most important international association for energy economists.
} 


\subsection{How RES change the German power system - a counterfactual approach [Paper 1]}

The expansion of RES in Germany has been successful so far, which lead to an increase in RES feed-in from 33 TWh in 2000 to 187 TWh in 2017 (BMWi, 2019b). Despite this huge expansion, at least once a year a public debate about RES and their governmental support ignites (Joffe, 2013; Weingartner and Schäfers, 2015; Schmidbauer, 2016; Wetzel, 2017). Arguments often are that RES are too expensive, or that they have no effect on $\mathrm{CO}_{2}$ emissions, which raises the question: what would the German power system without RES look like?

\section{Methodological approach}

Questions that consider alternative developments are referred to as counterfactual thinking (Epstude and Roese, 2008). It is used in many scientific fields to analyze interactions and understand the impact of single events (He et al., 2013). Especially in environmental science, the counterfactual approach can be helpful to examine the impact of a policy, as many input factor interact or correlate (Ferraro, 2009). Therefore, a scenario is created where the policy is not implemented, which can then be compared to the real world (Lankosko and Ollikainen, 2013). This approach is applied to analyze the impact of RES on the German power market.

To address this question a model coupling approach is chosen. First, the counterfactual scenario is developed and the counterfactual power generation portfolio is calculated using the investment module of the power market model ELTRAMOD. Secondly, the counterfactual power generation portfolio is applied in the dispatch module of ELTRAMOD to calculate the effects of RES on the power market. For these two modules, this approach allows to differentiate the underlying assumptions and input data. For the investment module, the input data are historic expectations, while the dispatch model uses real data. Hereby, it is possible to separate the investment decision, which is based on the expected fuel prices, and the power plant dispatch, which is based on current fuel prices. Figure 7 shows an overview of the applied methodology.

The starting point of the analysis is the historic power generation portfolio of 2006, because at this point in time RES did not have an impact (Diekmann et al., 2007; Wissen and Nicolosi, 2007; Sensfuß, 2011). The fuel prices for the model are historic expectations from 6 years back, which allows for considering the construction time for power plants. This period is typically between $5-10$ years (Ford, 1997; Haszeldine, 2009). Further assumptions regarding the counterfactual scenario are structured using the political, economic, social and technological (PEST) framework. Strategic management applies this approach to gain an overview of the most important impact factor of market developments (Clulow, 2005). Based on these assumptions and inputs, the model calculates the counterfactual power generation portfolio. 


\section{Results and key findings}

One of the results of the scenario comparisons is the counterfactual power generation portfolio. For 2015 it is about $8 \mathrm{GW}$ larger than the historic power generation portfolio or, in other words, RES have avoided $8 \mathrm{GW}$ of conventional capacities. These capacities are mainly hard coal capacities (7 GW). The rest are gas-fired capacities $(1 \mathrm{GW})$ that are not decommissioned due to better market conditions in the counterfactual scenario. These additional capacities reduce the cost for power supply especially for medium load levels, since RES often reduced this specific load level.

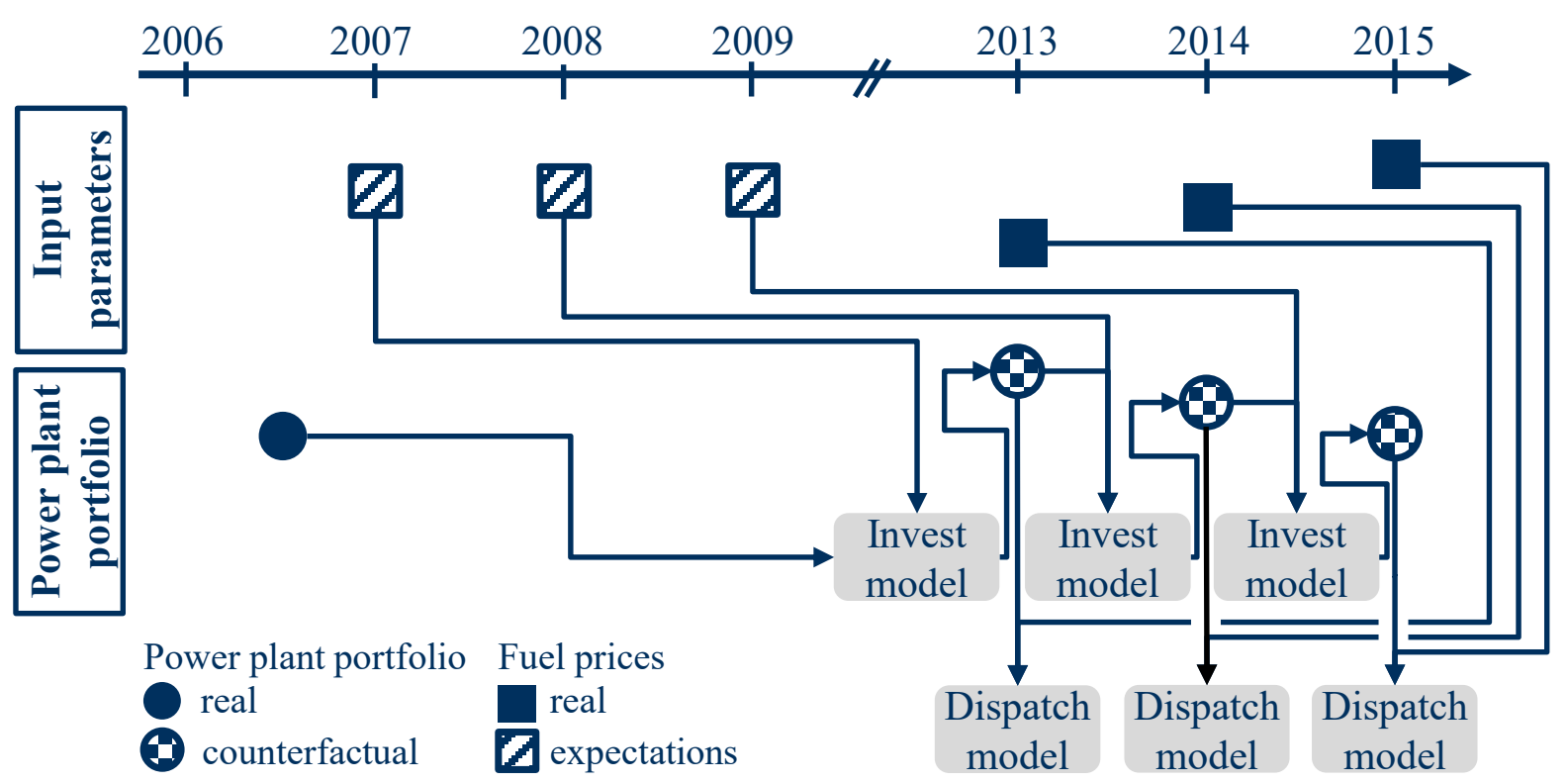

Figure 7: Overview of methodology (own illustration based on Anke (2019))

As for the impact of RES on the power market, they reduced the power price by $18.7 \mathrm{EUR} / \mathrm{MWh}$ in 2015. This decrease is the result of three effects: first, RES push expensive power plants out of the merit order (10 EUR / MWh). Second, less conventional generation decreases the demand for EUAs and reduce their price, which lowers the variable costs for most power plants and, thereby, the wholesale prices (-12.2 EUR / MWh). Third, the additional conventional capacities lower the price in the counterfactual scenario because they reduce power generation from expensive peak load power plants (+3.5 EUR / MWh). The impact of RES is not limited to the power wholesale price. They, furthermore, reduce the full load hours of the mid load power plants such as hard coal and gas-fired power plants, especially highly efficient combined cycle gas turbines. Additionally, the trade balance is greatly affected by German RES because their cheap power contributes strongly to the German power exports. In summary, this paper contributes to the literature threefold: First, it lays out in detail how a counterfactual scenario can be constructed in energy economics. It provides a structured framework for the assumptions, which allow the development of a plausible counterfactual scenario. This can be a 
foundation for the evaluation of other policies. Secondly, the analysis proofed the theory that RES influence the conventional power generation portfolio and, in Germany, avoid investments in about $8 \mathrm{GW}$ conventional capacity. Thirdly, these avoided investments dampen the merit-order effect, showing that the power market adapts to RES.

\section{Organizational integration}

The article is a work in single authorship and is published in Zeitschrift für Energiewirtschaft as

Anke, C. How Renewable Energy Is Changing the German Energy System-a Counterfactual Approach. Z Energiewirtsch 43, 85-100 (2019). https://doi.org/10.1007/s12398-019-00253-w

VHB-JOURQUAL: C (impact factor: 0.62)

Preliminary stages of this research were presented at the workshop of the society for operations research in Ulm in March 2018.

\subsection{Calculating the impact of German renewable energy source on the carbon emissions - a method comparison [Paper 2]}

Monitoring the impact of RES on the carbon emissions is important because it allows policy makers to adapt the policies when needed. Furthermore, countries participating in the Paris Agreement need to report their emissions reduction through RES. Calculating these reductions is not easy as a power systems carbon emission depends on a lot of factors such as fuel prices, demand and more. Furthermore, RES change the power plant dispatch in the short-term and alter the power generation portfolio in the long-term as shown in paper 1.

For calculating the effect of RES, there are several approaches that can be categorized in three groups (Holttinen et al., 2015):

(1) displacement estimation

(2) econometric methods (ECO)

(3) dispatch models (DIS)

Holttinen et al. (2015) provide a concise overview of studies estimating the impact of RES and compare them. However, the studies considered analyze different time periods and regions, which strongly limits their comparability. The second paper compares the advantages and disadvantages of the carbon emission reduction from RES for all three methods for the years 2016 and 2017. The focus of the analysis is the German power market, because it has many interconnections with neighboring countries. This is because it is located in the center of Europe. Furthermore, it has a high share of RES and a heterogeneous power generation portfolio, which make it an interesting case study. 


\section{Methodological approach}

In the first step the three approaches are qualitatively compared. Displacement estimations calculate the avoided emissions of RES based on the average emissions factor, which is multiplied with RES feed-in in its simplest form (Amor et al., 2014). The little data required make it easy to apply in international comparisons (Breyer, Koskinen and Blechinger, 2015). In contrast, econometric methods have a higher data need because they calculate the avoided emissions based on time series that consist at least of RES generation and emissions of the conventional generation. This allows to integrate dynamic effects (such as the interaction between technologies), as well as to consider time-lagged and non-linear effects (Cullen, 2013). The calculation of avoided emissions with dispatch models ${ }^{6}$ is based on a scenario comparison, with and without RES. For both scenarios, the dispatch model calculates the cost-optimal power plant dispatch for a defined power demand while considering operational restrictions. The differences in the results are caused by RES and are the foundation for the calculation of the avoided emissions of RES. The scenario without RES allows for the use of a counterfactual power generation portfolio (see paper 1) and thereby integrates long-term effects in the calculations.

In the second step, all three methods are implemented for Germany, and the avoided carbon emissions by RES are calculated. In addition, the effects of trade and pump-storage power plants, as well as the impact that RES have in the long run, are determined. This provides the basis for evaluating the methodical impact on the calculation of avoided emission from RES.

\section{Results and key findings}

Figure 8 presents an overview of the results for the avoided emissions in Germany for all three approaches ${ }^{7}$. The avoided $\mathrm{CO}_{2}$ emissions increase for all approaches from 2016 to 2017, which is caused by the increase in RES feed-in ${ }^{8}$. While the general trend is the same, the total avoided emissions are not. The results of the displacement approach and the dispatch model are comparable in size, whereas the econometric approach yields much lower values. This is due to the fact that it is not possible to calculate avoided emissions for non-fluctuating RES with this approach. The generation of non-fluctuating RES is rather constant and therefore the regression cannot find a relationship between their generation and the carbon emissions.

The strong assumptions in the displacement estimation may lead to comparable results for the years presented but this must not always be the case. In contrast, the dispatch model can consider more effects such as the long-term impact of RES. Hence its results have a higher explanatory power than the displacement estimation. The long-term impact is responsible for up to $10 \%$ of the avoided emissions,

\footnotetext{
${ }^{6}$ Bottom up power market models

${ }^{7}$ The implementation of the displacement estimation is called Primary Energy Equivalent (PEE) (Holttinen et al., 2015).

${ }^{8}$ The total feed-in from RES increased from 161.5 TWh in 2016 to 187.4 TWh in 2017 (BnetzA, 2018).
} 
which is the result of the counterfactual power plant. This impact can vary quite a lot since the dispatch of power plants depends on the current fuel and EUA prices.

Summarizing, all methods can provide valuable insights into the avoided emissions of RES. However, strong assumptions and the inability to consider dynamic effects limit the explanatory power the of the displacement estimations. Both are not an issue for an econometric approach, however it is limited to fluctuating RES. Besides considering non-fluctuating RES, a dispatch model can also calculate the long-term impact of RES and, hence, its results have the highest explanatory power.

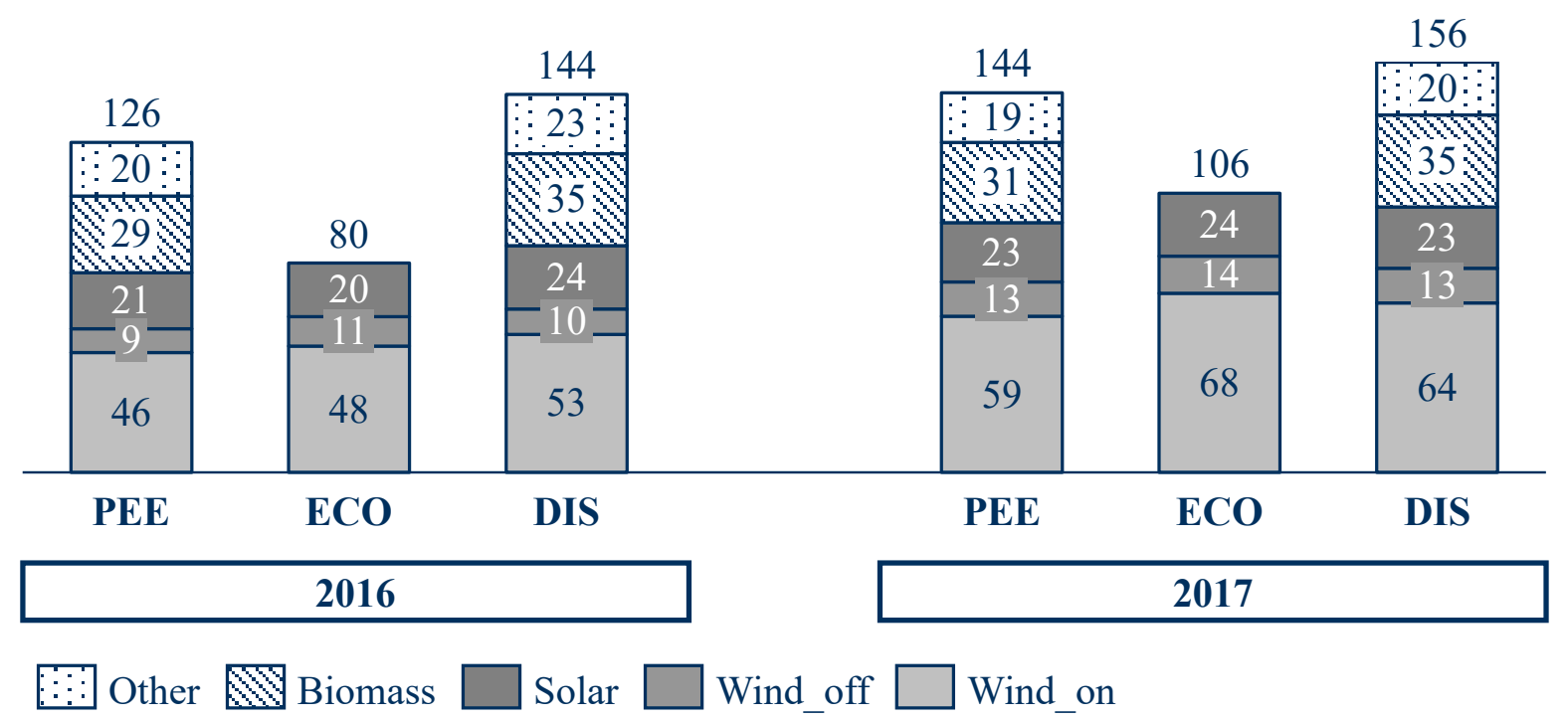

Figure 8: Avoided Carbon Emissions in the years in $\mathbf{M t} \mathbf{C O}_{2}$ (Anke, Schönheit and Möst, no date)

This study contributes to the existing research twofold: First, the paper examines the existing methods for analyzing the impact of renewables on carbon emission reductions. For each method the strengths and limitations are analyzed. Second, a case study for Germany is presented, in which all methods are implemented and the avoided $\mathrm{CO}_{2}$ emissions of RES in the power market are calculated. In case of the dispatch model this also includes an approach to consider the long-term effects of RES. The results of the case study are the basis for the evaluation of the methods.

\section{Organizational integration}

This paper is written in co-authorship with David Schönheit and Dominik Möst. Major parts of the design of the study were done by Carl-Philipp Anke. Dominik Möst supported the design phase with his valuable inputs especially with regard to the storyline and structural aspects. David Schönheit implemented the econometric model while Carl-Philipp Anke developed the bottom up dispatch model and applied the displacement estimation. David Schönheit and Carl-Philipp Anke discussed the results with Dominik Möst. Large parts of the manuscript were formulated by Carl-Philipp Anke. David 
Schönheit was responsible for the parts regarding the econometric model and supported the other parts, as well as Dominik Möst, with valuable feedback.

The article is published in Zeitschrift für Energiewirtschaft as

Anke, C.-P.; Schönheit, D.; Möst, D.; Measuring the Impact of Renewable Energy Sources on Power 5Sector Carbon Emissions in Germany-a Methodological Inquiry. Z Energiewirtsch 43, 1-23 (2021). https://doi.org/10.1007/s12398-020-00292-8

VHB-JOURQUAL: C (impact factor: 0.62)

Preliminary stages of this research have been presented at the Student Chapter of GEE in in May 2018 in Cologne and at the 42nd International Conference of the IAEE in May 2019 in Montreal.

\subsection{Coal phase-outs and carbon prices: Interactions between $\mathrm{EU}$ emission trading and national carbon mitigation policies [Paper 3]}

The EU ETS is the core of Europe's climate protection policy. Additionally, several EU member states have implemented further measures to reduce their national carbon emissions. The measures include the coal phase-out and the expansion of RES. Both measures reduce national $\mathrm{CO}_{2}$ emissions, but do not reduce the carbon cap and hence the overall emissions do not decrease due to the waterbed effect (Rosendahl, 2019). It can be overcome by a cancelation of certificates, which has been possible since the new amendment of EU ETS in 2018 (EU, 2018). However, determining the amount of EUAs that need to be cancelled is tough. Literature, so far, mostly focused on the effect of RES on the EU ETS only (see for instance Weigt, Ellerman and Delarue (2013) or Figueiredo et al. (2019) among others). RES reduce the residual demand that has to be covered by conventional generation, which decreases the demand for EUAs. In contrast, the coal phase-out leads to a change in the structure of the power generation portfolio. With the coal phase-out, the technologies that benefit from low carbon prices ${ }^{9}$ must leave the market and, hence, lower carbon prices have a lower effect on the emissions.

\section{Methodological approach}

The structural change in the power generation portfolio of many European countries can be analyzed best with a fundamental model. Here, the changed structure of the power generation portfolio can be considered together with its impact on the EUA prices (Möst and Fichtner, 2009; Hobbie, Schmidt and Möst, 2019). In order to analyze this research question the fundamental model ELTRAMOD is applied.

\footnotetext{
${ }^{9}$ Hard coal and lignite have a higher emission factor than gas and hence are affected more strongly by the carbon price (UBA, 2016).
} 
It is used in three scenarios:

- $\quad \mathrm{NoCPO}$ - no coal phase-out in Europe

- $\mathrm{CPO}$ - coal phase-out in Europe

- $\mathrm{CPOwC}$ - coal phase-out in Europe with additional cancellations

Based on these scenarios the impact of the coal phase-out on the EU ETS is determined. Furthermore, the necessary cancellations are analyzed in the scenario CPOwC. Additionally, the impact of RES is calculated in a sensitivity analysis. The scenarios are calculated for the years 2014 (reference year), 2025 ( $\sim 20 \%$ carbon cap reduction) and 2030 ( $\sim 30 \%$ carbon cap reduction).

\section{Results and key findings}

The scenario NoCPO provides a baseline and it shows that without a coal phase-out the EUA price would increase from $6 \mathrm{EUR} / \mathrm{t}$ to $28 \mathrm{EUR} / \mathrm{t}$ in 2025 and to $48 \mathrm{EUR} / \mathrm{t}$ in 2030. This moderate increase in carbon price, although the carbon cap tightens by $30 \%$, is the result of a strong expansion of RES. In contrast, in the scenario CPO, in which about $80 \mathrm{GW}$ of coal capacities are decommissioned until 2030, EUAs lost all their material value. Due to the coal phase-out, the demand for EUAs drops below the available number of EUAs, making the EU ETS ineffective. In order for the EU ETS to maintain its ability to provide price signals for carbon mitigation, EUA have to be deleted. A deletion of $50 \%$ of the EUAs leads to prices higher than in the CPO scenario. The sensitivity analysis shows that around $30 \%$ of EUAs need to be deleted to keep the price level constant.

The sensitivity analysis for the RES expansion demonstrates clearly that national measures need to be coupled with a cap reduction of EU ETS. When the RES expansion is increased, and therefore the residual demand decreases, it results in a higher share of carbon-intensive coal generation in the conventional generation. Compared to when the expansion of RES is decreased, the share of coal decreases. This is caused by a constant carbon cap in both cases, with higher and lower RES expansion and, in the end, comparable total emissions. This clearly shows the welfare losses of current regulations. Nonetheless, the expansion of RES is important to achieve the urgently needed transformation of the energy system. Therefore, it is important to keep EUA prices stable in the current regulatory framework, because otherwise there would be fewer incentives for the expansion of RES.

The third paper contributes to the literature by examining the effects of the interaction between international and national carbon mitigation policies. It analyzes the impact of the coal phase-out on the EU ETS and its capability to provide incentives for carbon mitigation. The analysis applies a bottom-up power market model. This approach allows to consider fundamental changes such as the phase-out of technologies, and to evaluate its impact on the carbon and power markets implemented. The calculated carbon prices allow for an investigation of the impacts on the EU ETS. Furthermore, this analysis calculates the amount of EUAs to be cancelled to ensure the functioning of the EU ETS when coal is phased-out across Europe. 


\section{Organizational integration}

This paper is written in co-authorship with Hannes Hobbie, Steffi Schreiber and Dominik Möst. The design of the study was done in joint work of the co-authors. Steffi Schreiber was responsible for the data and literature review and supported by Carl-Philipp Anke. He furthermore developed the theoretical framework. The model was developed and operated by Hannes Hobbie. Carl-Philipp Anke was in charge of the evaluation of the results and their visualization. On this basis the results were discussed among the co-authors. According to their responsibilities the co-authors wrote parts of the manuscript. Dominik Möst supported the preparation with valuable comments and feedback.

The article is published in in Energy Policy as

Anke, C.-P.; Hobbie, H.; Schreiber, S.; Möst, D.: Coal phase-outs and carbon prices: Interactions between EU emission trading and national carbon mitigation policies; 2020; Energy Policy; 144; https://doi.org/10.1016/j.enpol.2020.111647

VHB-JOURQUAL: B (impact factor: 4.88)

Preliminary stages of this research have been presented at the 42nd International Conference of the IAEE in May 2019 in Montreal.

\subsection{Stranded Asset Risk and Political Uncertainty: The Impact of the Coal Phase-out on the German Coal Industry [Paper 4]}

The coal phase-out was recommended by the coal commission and the German government undertook first steps towards its implementation in 2019, since it is an important step for climate mitigation in Germany (BMWi, 2019a, 2020). On the one hand, Germany is failing to meet its voluntarily set obligations (BMU, 2018) and, on the other hand, coal is the largest $\mathrm{CO}_{2}$ emitter of the German power sector (UBA, 2020a).

These developments question the valuation of the coal industry in Germany. Costs concerning the loss in valuation due to the phase-out of coal can thereby be specified as "stranded assets" (Jewell et al., 2019). Furthermore, compensation payments can be based on the loss in valuation. However, the topic of compensation is discussed controversially. On the one hand it is argued that the industry is "too big to fail" and, hence, needs compensations while, on the other hand, studies indicate that the phase-out is in line with the constitution and compensations are legally controversial.

\section{Methodological approach}

To analyze the stranded asset risk of a phase-out in 2038 and 2030, a simplified fundamental power market model has been developed. It calculates the revenues and costs based on the market clearing price for base and peak load and the respective full load hours. The model is set up as a Monte-Carlo- 
analysis that allows to cover uncertainties, which is especially important in climate-related models (Cai, Judd and Lontzek, 2017; Barnett, Brock and Hansen, 2020). The model calculates the future cash flows for hard coal and lignite power plants. Afterwards the model derives the net present value (NPV) of the hard coal and lignite power plants. Based on a scenario comparison, the loss in valuation is calculated for a phase-out in 2038 and 2030. In order to cover the impact of RES expansion a sensitivity analysis for the base load is conducted.

Three scenarios are developed:

- Delaying Climate Action Scenario (DCAS) - no coal phase-out and low carbon prices

- Maintaining Climate Action Scenario (MCAS) - coal phase-out in 2038 and medium EUA prices

- Enforcing Paris Agreement Scenario (EPAS) - coal phase-out in 2030 and high EUA prices

\section{Results and key findings}

An overview of the results is shown in Table 2. The valuation of the coal industry decreases by -0.4 bn EUR if the lignite capacities are phased-out until 2038. This is driven by a reduction of losses for hard coal power plants that are likely to not operate profitably while the earnings of lignite are cut due to the shorter operating time. In contrast to a phase-out in 2038, an early phase-out in 2030 leads to a strong decrease in valuation of lignite (-14.5 bn EUR compared to DCAS), while the impact on the valuation for hard coal is moderate. Higher carbon prices reduce the profit margin so that only fixed costs can be covered. Due to the limited cash flow the shorter operating period only plays a minor role. However, an early phase-out would reduce Germany's emissions by $0.8 \mathrm{Gt} \mathrm{CO}_{2}$ more and hence bring Germany closer to fulfilling the reductions goals in the Paris Agreement. Furthermore, the sensitivity analysis for the RES expansion shows that the valuation of lignite reacts very sensitively to a further deployment of RES. It reduces, on the one hand, the power prices, but also, on the other, the full load hours of lignite. Hard coal is much less affected because it has only limited operations in the reference case.

This study contributes to the literature on the effects of the coal phase-out by quantifying the stranded assets risk. Thereby, it adds to the current discussion on possible compensation payments, indicating that for hard coal power plants no compensations should be paid, while operators for lignite power plants face substantial losses. It further indicates that in the case of a tightening of the climate legislation, the phase-out time becomes less important, as lignite power plants lose their profitability firstly due to higher carbon costs. Furthermore, the interconnection between the physical power plant and the financial asset those value is decreased, possess a risk to the investors2. In light of the uncertainty of further developments, the findings of this study underline the need of incorporation of climate risks into investment decisions. 
Table 2: Valuation of hard coal and lignite power plants in the different scenarios

\begin{tabular}{lccc} 
& Lignite & Hard & Overall \\
\hline \hline DCAS & 14.0 & -3.8 & 10.2 \\
\hline MCAS & 10.9 & -1.1 & 9.8 \\
\hline delta MCAS-DCAS & $(-3.1)$ & $(2.7)$ & $(-0.4)$ \\
\hline EPAS & -0.5 & -4.1 & -4.6 \\
\hline delta EPAS-DCAS & $(-14.5)$ & $(-0.3)$ & $(-14.8)$ \\
\hline $\begin{array}{c}\text { delta EPAS-MCAS } \\
\quad(\text { own table) }\end{array}$ & $(-11.4)$ & $(-3.0)$ & $(-14.4)$ \\
\end{tabular}

\section{Organizational integration}

This paper is written in co-authorship with Miriam Breitenstein, Duc K. Nguyen and Thomas Walther. The design of the study was done in joint work of Miriam Breitenstein, Carl-Philipp Anke and Thomas Walther. Miriam Breitenstein was responsible for the literature review and the data preparation. The market model was developed by Miriam Breitenstein, Carl-Philipp Anke and Thomas Walther. The results were discussed and analyzed among the co-authors. Miriam Breitenstein prepared large parts of the manuscript while the other co-authors supported her with feedback and wrote parts themself.

The article is accepted in The Energy Journal as

Breitenstein, M.; Anke, C.-P.; Nguyen, D. K.; Walther, T.; Stranded Asset Risk and Political Uncertainty: The Impact of the Coal Phase-out on the German Coal Industry. Energy Journal 43 (5) (2021). https://doi.org/10.5547/01956574.43.5.mbre

VHB-JOURQUAL: not ranked (impact factor: 2.46)

\subsection{The expansion of RES and the EU ETS - valuable addition or conflicting instruments? [Paper 5]}

The fifth and final paper deals with the interaction of the further expansion of RES and the EU ETS. So far RES have gained a big market share and are responsible for about $35 \%$ of power generation. The further expansions gain importance since the demand for power is likely to rise in the future due to sector coupling (e.g. the electrification of the heat and mobility sector). Additionally, conventional generation is phased-out, so that RES need to provide a greater share of the power generation.

Bertsch and Di Cosmo (2018) show that the economic feasibility of RES increases until 2030. The phase-out of coal and the thereby increased speed of the energy transition might increase their profitability further because technologies with low marginal costs leave the market, which increases the 
wholesale price. With increased RES shares, the risk of cannibalization effects rises, which puts the profit margins for RES under pressure (Simshauser, 2018). This is caused by two things. First, the merit order effect (which reduces the national wholesale price) and, second, the reduction of the demand for EUAs, which lowers their price (Winkler et al., 2016). Due to the cannibalization effects, additional support for RES can become necessary. The costs and benefits of the expansion are distributed differently. The costs, e.g. for the investment as well as the other costs (e.g. land use, local opposition), occur nationally, while the benefits occur on a European scale due to lower wholesale power and EUA prices.

\section{Methodological approach}

Against this background, the effect of different national RES deployment strategies is investigated while considering the EU ETS. The analysis is based on a scenario comparison. The first scenario considers national policy measures (NaPoM) for RES expansion, while the second scenario takes international (coordinated) climate actions (ICA) into account. In ICA the optimal RES expansion in each country is calculated, while in NaPoM the RES expansion is based on the drafted National Energy and Climate Plans of each country (EC, 2019b). The scenarios are applied in the bottom up fundamental market model ELTRAMOD. It comprises the cost efficient power plants dispatch and investment using an optimization algorithm. Besides power prices and the investments in different technologies it computes the carbon prices endogenously based on a carbon cap it introduces (Hobbie, Schmidt and Möst, 2019). This allows a direct interaction of investments in RES and the carbon price. The model covers the EU member states as well as Norway and Switzerland, modelling the national power markets as zones.

\section{Results and key findings}

Due to the phase-out of coal, new conventional capacities are needed in both scenarios. They add up to about $80 \mathrm{GW}$ in both scenarios, which equals roughly the phased-out capacities. Although the phased-out capacities are replaced, the conventional generation decreases from $66 \%$ to $48 \%$ of total power generation. The power is produced by RES that increase their production volume from about 1,150 to $1,850 \mathrm{TWh}$. The conventional capacities are needed as back up for times with low RES feedin. Furthermore, in both scenarios power prices increase compared to the reference year 2017, which has three reasons: higher EUA prices, increased gas prices and less conventional base load capacity.

In the $\mathrm{NaPoM}$ scenario the higher investments in RES lead to a lower EUA price (26 EUR / $\mathrm{t} \mathrm{CO}$ ), but increase the overall system costs by $13 \%$, indicating that national targets are not cost efficient. Furthermore, it can be concluded that additional RES investments increase the system costs, but do not support climate mitigation due to the waterbed effect. These additional RES reduce the profits of RES and hence may lead to a further need for governmental support schemes. Both issues can be solved when deleting EUAs. 
With regard to the moderate EUA price in the ICA scenario, this indicates that the EU ETS is perfectly able to produce sufficient price signals to incentivize the expansion of RES and the mitigation of carbon emissions. Thereby, the model favors cheap wind onshore, while in NaPoM more PV and wind offshore is installed. This might be due to the fact that policy makers have social acceptance in mind, which is higher for these technologies (Bertsch et al., 2016; Sonnberger and Ruddat, 2016).

General statements regarding the effects of national RES targets on the economic feasibility of RES are difficult. On the one hand, the economic feasibility depends on many input factors, which can differ among the countries and, on the other hand, the economic feasibility is strongly determined by the total installed RES capacities. When the RES share is too high, cannibalization effects occur. While if only limited RES capacities are installed, their profitability is high and further RES would be welfare enhancing. In the case studies, both cases have been analyzed. In the Netherlands, for example, the government has committed to expanding RES to $66 \%$ of the power generation, leading to strong decreases in power prices, and to a NPV of $-1 \%$ for wind onshore at the same time. So, the strong increase in RES capacities make further governmental RES support schemes necessary. As opposed to this, in the case of Italy the expansion of RES is limited to 56\%. Here, the NPV is high, with $15 \%$ for wind onshore indicating that investors have incentives to invest into further capacities. Both cases contribute to a debate on justice, as the costs are local, but the benefits are international. This can potentially heat up social acceptance conflicts. Additionally, the further RES expansion questions the power market design. Here, further research is needed on how power markets can be organized with higher RES shares.

This paper contributes to the literature by investigating the impact of the nationally set RES targets and their interaction with the EU ETS. It is shown that lower carbon prices are not necessarily economically beneficial and that the EU ETS is perfectly able to provide sufficient price signals for the expansion of RES. Furthermore, it is shown that in the current power market design high shares of RES need governmental support schemes. Hence, a further development of the power market design is necessary.

\section{Organizational integration}

This paper is written in co-authorship with Dominik Möst. The study was designed by Dominik Möst and Carl-Philipp Anke. Carl-Philipp Anke prepared the literature review as well as the data and developed the applied power market model. The results of the study were discussed among the coauthors. Afterwards Carl-Philipp Anke prepared the manuscript. Dominik Möst supported him with valuable feedback and comments. 
The article is published in Energy Policy as

Anke, C.-P.; Möst, D.; The expansion of RES and the EU ETS - valuable addition or conflicting instruments?, 2021, Energy Policy, 145, https://doi.org/10.1016/j.enpol.2020.112125

VHB-JOURQUAL: B (impact factor: 4.88)

Preliminary stages of this research were presented at the OR conference in September 2019 in Dresden. 


\section{References}

Amor, M. Ben et al. (2014) 'Influence of wind power on hourly electricity prices and GHG (greenhouse gas) emissions: Evidence that congestion matters fromOntario zonal data', Energy, 66, pp. 458-469. doi: 10.1016/j.energy.2014.01.059.

Anke, C.-P. (2019) 'How renewable energy is changing the German energy system - a counterfactual approach', Zeitrschrift für Energiewirtschaft, 43(2), pp. 85-100. doi: https://doi.org/10.1007/s12398019-00253-w.

Anke, C.-P., Schönheit, D. and Möst, D. (no date) 'Analysis of methods for calculating the carbon mitigation of renewable energy sources', (Under Review).

Barnett, M., Brock, W. and Hansen, L. P. (2020) Pricing uncertainty induced by climate change, Review of Financial Studies. NO. 2019-109. Chicago. doi: 10.1093/rfs/hhz144.

Bartholdsen et al. (2019) 'Pathways for Germany's Low-Carbon Energy Transformation Towards 2050', Energies, 12(15), p. 2988. doi: 10.3390/en12152988.

Bertsch, V. et al. (2016) 'Public acceptance and preferences related to renewable energy and grid expansion policy: Empirical insights for Germany', Energy. Elsevier Ltd, 114, pp. 465-477. doi: 10.1016/j.energy.2016.08.022.

Bertsch, V. and Di Cosmo, V. (2018) Are Renewables Profitable in 2030? A Comparison between Wind and Solar Across Europe. 028.2018. Milano. doi: 10.2139/ssrn.3241987.

BMU (2018) 'Klimaschutzbericht 2018'. Berlin, p. 184. Available at: https://www.umweltbundesamt.at/fileadmin/site/publikationen/REP0660.pdf.

BMWi (2019a) Abschlussbericht Kohlekommission. Berlin. Available at: https://www.bmwi.de/Redaktion/DE/Downloads/A/abschlussbericht-kommission-wachstumstrukturwandel-und-beschaeftigung.pdf?_blob=publicationFile\& $\mathrm{v}=4$.

BMWi (2019b) Erneuerbare Energien in Zahlen, Erneuerbare Energien in Zahlen. Berlin. Available at: $\quad$ https://www.bmwi.de/Redaktion/DE/Publikationen/Energie/erneuerbare-energien-in-zahlen2018.pdf?_blob=publicationFile\&v=22.

BMWi (2020) Kabinett beschließt Kohleausstiegsgesetz. Available at: https://www.bmwi.de/Redaktion/DE/Pressemitteilungen/2020/20200129-kabinett-beschliesstkohleausstiegsgesetz.html (Accessed: 1 April 2020).

BnetzA (2018) Monitoringbericht 2018. Bonn. Available at: https://www.bundesnetzagentur.de/SharedDocs/Downloads/DE/Allgemeines/Bundesnetzagentur/Publi kationen/Berichte/2018/Monitoringbericht_Energie2018.pdf?_blob=publicationFile\&v=6. 
Böhringer, C. et al. (2016) 'Good things do not always come in threes: On the excess cost of overlapping regulation in EU climate policy', Energy Policy. Elsevier, 94(2007), pp. 502-508. doi: 10.1016/j.enpol.2015.12.034.

Breyer, C., Koskinen, O. and Blechinger, P. (2015) 'Profitable climate change mitigation: The case of greenhouse gas emission reduction benefits enabled by solar photovoltaic systems', Renewable and Sustainable Energy Reviews, 49, pp. 610-628. doi: 10.1016/j.rser.2015.04.061.

Cai, Y., Judd, K. L. and Lontzek, T. S. (2017) The Social Cost of Carbon with Economic and Climate Risk. $18113 . \quad$ STANFORD. Available at: https://www.hoover.org/sites/default/files/research/docs/18113-judd1.pdf.

Chaton, C., Creti, A. and Peluchon, B. (2015) 'Banking and back-loading emission permits', Energy Policy. Elsevier, 82(1), pp. 332-341. doi: 10.1016/j.enpol.2015.01.023.

Cludius, J. et al. (2014) 'The merit order effect of wind and photovoltaic electricity generation in Germany 2008-2016 estimation and distributional implications', Energy Economics. North-Holland, 44, pp. 302-313. doi: 10.1016/j.eneco.2014.04.020.

Clulow, V. (2005) 'Futures dilemmas for marketers: can stakeholder analysis add value?', European Journal of Marketing, 39(9/10), pp. 978-997. doi: 10.1108/03090560510610671.

Cullen, J. A. (2013) 'Measuring the Environmental Benefits of Wind-Generated Electricity', American Economic Journal: Economic Policy, 5(4), pp. 107-133. doi: 10.1257/pol.5.4.107.

Diekmann, J. et al. (2007) Fachgespräch zum „Merit-Order-Effekt“. Berlin. Available at: https://www.bmu.de/fileadmin/bmu-

import/files/pdfs/allgemein/application/pdf/thesenpapier_meritordereffekt.pdf (Accessed: 26 April 2018).

EC (2019a) 2030 climate \& energy framework, Homepage. Available at: https://ec.europa.eu/clima/policies/strategies/2030_en\#tab-0-0 (Accessed: 24 February 2020).

EC (2019b) National energy and climate plans (NECPS), European Commission. Available at: https://ec.europa.eu/energy/en/topics/energy-strategy-and-energy-union/national-energy-climate-plans (Accessed: 3 February 2020).

EEA (2019) Greenhouse gas emissions by aggregated sector. Available at: https://www.eea.europa.eu/data-and-maps/daviz/ghg-emissions-by-aggregated-sector-5\#tabdashboard-02 (Accessed: 17 August 2020).

Epstude, K. and Roese, N. J. (2008) 'The functional theory of counterfactual thinking', Personality and Social Psychology Review, 12(2), pp. 168-192. doi: 10.1177/1088868308316091.

EU (2004) RICHTLINIE 2004/101/EG DES EUROPÄISCHEN PARLAMENTS UND DES RATES. 
EU (2018) DIRECTIVE (EU) 2018/410 OF THE EUROPEAN PARLIAMENT AND OF THE COUNCIL. EU.

Europe Beyond Coal (2020) COAL EXIT TRACKER. Available at: https://beyond-coal.eu/data/ (Accessed: 24 March 2020).

Ferraro, P. J. (2009) 'Counterfactual thinking and impact evaluation in environmental policy', New Directions for Evaluation. Wiley-Blackwell, 2009(122), pp. 75-84. doi: 10.1002/ev.297.

Figueiredo, R. et al. (2019) 'Replacing coal-fired power plants by photovoltaics in the Portuguese electricity system', Journal of Cleaner Production, 222, pp. 129-142. doi: 10.1016/j.jclepro.2019.02.217.

Ford, A. (1997) 'System Dynamics and the Electric Power Industry', System Dynamics Review. WileyBlackwell, 13(1), pp. 57-85. doi: https://doi.org/10.1002/(SICI)1099-1727(199721)13:1<57::AIDSDR117>3.0.CO;2-B.

Graf, C. and Wozabal, D. (2013) 'Measuring competitiveness of the EPEX spot market for electricity', Energy Policy. Elsevier, 62, pp. 948-958. doi: 10.1016/j.enpol.2013.07.052.

Graichen, P. and Matthes, F. C. (2018) Vom Wasserbett zur Badewanne. Berlin. Available at: https://www.agora-energiewende.de/veroeffentlichungen/vom-wasserbett-zur-badewanne/ (Accessed: 13 August 2019).

Haszeldine, R. S. (2009) 'Carbon capture and storage: how green can black be?', Science (New York, N.Y.). American Association for the Advancement of Science, 325(5948), pp. 1647-52. doi: $10.1126 /$ science. 1172246 .

He, J. et al. (2013) 'A counterfactual scenario simulation approach for assessing the impact of farmland preservation policies on urban sprawl and food security in a major grain-producing area of China', Applied Geography. Pergamon, 37(1), pp. 127-138. doi: 10.1016/j.apgeog.2012.11.005.

Hillemacher, L. and Fichtner, W. (2012) 'Aanalyse des Einflusses des Emissionshandels auf Produktion und Emissionen ausgewählter Industriesektoren', in Symposium Energieinnovation. Graz, pp. 1-12.

Hobbie, H., Schmidt, M. and Möst, D. (2019) 'Windfall Profits in the Power Sector during Phase III of the EU ETS: Interplay and Effects of Renewables and Carbon Prices', Journal of Cleaner Production, 240. doi: https://doi.org/10.1016/j.jclepro.2019.118066.

Holttinen, H. et al. (2015) 'Reduction of CO2 emissions due to wind energy - methods and issues in estimating operational emission reductions', 2015 IEEE Power \& Energy Society General Meeting, pp. 1-5. doi: 10.1109/PESGM.2015.7286288. 
IPCC (2014) Climate Change 2014: Mitigation of Climate Change. Contribution of Working Group III to the Fifth Assessment Report of the Intergovernmental Panel on Climate Change, Cambridge University Press. Edited by O. Edenhofer et al. Cambridge, United Kingdom and New York, NY, USA.: Cambridge University Press. doi: 10.1017/CBO9781107415416.

IPCC (2015) 'Climate Change 2014: Synthesis Report'. Edited by Core Writing Team, R. K. Pachauri, and L. A. Meyer. Geneva, Switzerland. Available at: https://www.ipcc.ch/pdf/assessmentreport/ar5/syr/SYR_AR5_FINAL_full_wcover.pdf(Accessed: 9 April 2018).

IPCC (2018) 'Global warming of $1.5^{\circ} \mathrm{C}$ An IPCC Special Report on the impacts of global warming of $1.5^{\circ} \mathrm{C}$ above pre-industrial levels and related global greenhouse gas emission pathways, in the context of strengthening the global response to the threat of climate change s'. Edited by V. Masson-Delmotte et al.

IRENA (2016) The Power to Change: Solar and Wind Cost Reduction Potential to 2025, Inernational Renewable Energy Agency. Available at: https://www.irena.org//media/Files/IRENA/Agency/Publication/2016/IRENA_Power_to_Change_2016.pdf (Accessed: 11 February 2020).

Jewell, J. et al. (2019) 'Prospects for powering past coal', Nature Climate Change. Springer US, 9(8), pp. 592-597. doi: 10.1038/s41558-019-0509-6.

Joffe, J. (2013) 'Der Wahnsinn, der aus der Steckdose fließt', Die Zeit. Available at: https://www.zeit.de/wirtschaft/2013-10/erneuerbare-umlage-kritik (Accessed: 17 April 2019).

Ladwig, T. (2018) Demand Side Management in Deutschland zur Systemintegration erneuerbarer Energien. TU Dresden. Available at: http://nbn-resolving.de/urn:nbn:de:bsz:14-qucosa-236074.

Lankosko, J. and Ollikainen, M. (2013) 'Counterfactual approach for assessing agri-environmental policy: The case of the Finnish water protection policy.', Revue d'Etudes en Agriculture et Environnement. European Association of Agricultural Economists, 94(2), pp. p165-193. doi: 10.4074/S1966960713012022.

Löschel, A. et al. (2020) Energiewirtschaft. 4 th. Berlin/Boston: De Gruyter Oldenbourg. doi: 10.1515/9783110556339.

Mezösi, A., Szabó, L. and Szabó, S. (2018) 'Cost-efficiency benchmarking of European renewable electricity support schemes', Renewable and Sustainable Energy Reviews, 98, pp. 217-226. doi: https://doi.org/10.1016/j.rser.2018.09.001.

Möst, D. and Fichtner, W. (2009) 'Einführung zur Energiesystemanalyse', in Möst, D., Fichtner, W., and Grunwald (eds) Energiesystemanalyse. Karlsruhe, pp. 11-31. 
Möst, D. and Genoese, M. (2009) 'Market power in the German wholesale electricity market', The Journal of Energy Markets, 2(2), pp. 47-74. doi: 10.21314/jem.2009.031.

Perino, G. (2018) 'New EU ETS Phase 4 rules temporarily puncture waterbed', Nature Climate Change, 8(4), pp. 262-264. doi: 10.1038/s41558-018-0120-2.

Praktiknjo, A. and Erdmann, G. (2016) 'Renewable electricity and backup capacities: An (un-) resolvable problem?', Energy Journal, 37, SI2, pp. 89-106. doi: 10.5547/01956574.37.SI2.apra.

Ragwitz, M. and Steinhilber, S. (2014) 'Effectiveness and efficiency of support schemes for electricity from renewable energy sources', Wiley Interdisciplinary Reviews: Energy and Environment, 3(2), pp. 213-229. doi: 10.1002/wene.85.

Rickels, W. et al. (2007) The determinants of allowance prices in the European emissions trading scheme: Can we expect an efficient allowance market 2008?, Kiel Working Paper. Kiel.

Rosendahl, K. E. (2019) 'EU ETS and the waterbed effect', Nature Climate Change. Springer US, 9, pp. 734-735. doi: 10.1038/s41558-019-0579-5.

Schmidbauer, J. (2016) 'Noch nie mussten die Verbraucher so viel für die Energiewende zahlen', Süddeutsche Zeitung. Available at: https://www.sueddeutsche.de/wirtschaft/eeg-oekostrom-umlagesteigt-auf-rekordwert-von-cent-1.3205215 (Accessed: 17 April 2019).

Schubert, D. K. J. (2016) Bewertung von Szenarien für Energiesysteme. TU Dresden. Available at: http://www.qucosa.de/fileadmin/data/qucosa/documents/20222/SchubertDaniel_BewertungvonSzenari enfürEnergiesystemeNeu.pdf (Accessed: 2 May 2018).

Sensfuß, F. (2011) Analysen zum Merit-Order Effekt erneuerbarer Energien, Fraunhofer-Gesellschaft zur Förderung der angewandten Forschung e. $V$. Karlsruhe. Available at: https://www.solarwirtschaft.de/fileadmin/content_files/Studie_Meritorder.pdf (Accessed: 29 April 2018).

Simshauser, P. (2018) 'On intermittent renewable generation \& the stability of Australia's National Electricity Market', Energy Economics. Elsevier B.V, 72, pp. 1-19. doi: 10.1016/j.eneco.2018.02.006.

Sonnberger, M. and Ruddat, M. (2016) Die gesellschaftliche Wahrnehmung der Energiewende Ergebnisse einer deutschlandweiten Repräsentativbefragung. 34. Stuttgart. doi: http://dx.doi.org/10.18419/opus-8894.

Thomson Reuters Datastream (2020). Available at: $\mathrm{https}$ //datastream.thomsonreuters.com/dsws/1.0/DSLogon.aspx?persisttoken=true\&appgroup=DSExtr anet\&srcapp $=$ Extranet\&srcappver $=1.0 \&$ prepopulate $=\&$ env $=\&$ redirect $=$ https: $/ /$ infobase. thomsonreuter s.com/infobase/ (Accessed: 12 April 2020). 
UBA (2016) CO2-Emissionsfaktoren für fossile Brennstoffe, Climate Change 27/2016. 27. Dessau. Available at: http://www.umweltbundesamt.de/sites/default/files/medien/1968/publikationen/co2emissionsfaktoren_fur_fossile_brennstoffe_korrektur.pdf.

UBA (2020a) Energiebedingte Emissionen. Available at: https:/www.umweltbundesamt.de/daten/energie/energiebedingte-emissionen\#energiebedingtetreibhausgas-emissionen (Accessed: 19 March 2020).

UBA (2020b) Entwicklung der Kohlendioxid-Emissionen der fossilen Stromerzeugung nach eingesetzten Energieträgern. Dessau-Roßlau. Available at: https://www.umweltbundesamt.de/bild/entwicklung-der-kohlendioxid-emissionen-der (Accessed: 26 August 2020).

UBA (2020c) ‘Entwicklung der spezifischen Kohlendioxid- Emissionen des deutschen Strommix in den Jahren 1990 - 2019'. Dessau-Roßlau, pp. 1-28. Available at: https://www.umweltbundesamt.de/sites/default/files/medien/1410/publikationen/2020-04-01_climatechange_13-2020_strommix_2020_fin.pdf.

UN (1998) REPORT OF THE CONFERENCE OF THE PARTIES ON ITS THIRD SESSION, HELD AT KYOTO FROM 1 TO 11 DECEMBER 1997.

UNFCCC (2015) ADOPTION OF THE PARIS AGREEMENT. Available at: https://unfccc.int/resource/docs/2015/cop21/eng/109r01.pdf(Accessed: 30 April 2018).

United Nations (1992) 'The United Nations Framework Convention on Climate Change'. UN.

Ventosa, M. et al. (2005) 'Electricity market modeling trends', Energy Policy, 33, pp. 897-913. doi: 10.1016/j.enpol.2003.10.013.

Weigt, H. (2009) 'Germany's wind energy: The potential for fossil capacity replacement and cost saving', Applied Energy, 86(10), pp. 1857-1863. doi: 10.1016/J.APENERGY.2008.11.031.

Weigt, H., Ellerman, D. and Delarue, E. (2013) 'CO2 abatement from renewables in the German electricity sector: Does a CO2 price help?', Energy Economics, 40, pp. S149-S158. doi: 10.1016/j.eneco.2013.09.013.

Weingartner, M. and Schäfers, M. (2015) Die Kritik an Ökostrom-Umlage wird lauter, Frankfurter Allgemeine Zeitung. Frankfurt. Available at: https://www.faz.net/aktuell/wirtschaft/energiepolitik/gabriel-muss-sich-fuer-teure-energiewende-undsteigende-eeg-umlage-verantworten-13858459.html (Accessed: 17 April 2019).

Wenders, J. T. (1976) 'Peak Load Pricing in the Electric Utility Industry', Source: The Bell Journal of Economics, 7(1), pp. 232-241. Available at: http://www.jstor.org/stable/3003198 (Accessed: 8 May 2018). 
Wetzel, D. (2017) 'Handwerk fordert das Aus der „ungerechten“ Energiewende’, Die Welt. Available at: https://www.welt.de/wirtschaft/article166698465/Handwerk-fordert-das-Aus-der-ungerechtenEnergiewende.html.

Winkler, J. et al. (2016) 'The market value of renewable electricity - Which factors really matter?', Applied Energy. Elsevier Ltd, 184, pp. 464-481. doi: 10.1016/j.apenergy.2016.09.112.

Wissen, R. and Nicolosi, M. (2007) 'Anmerkungen zur aktuellen Diskussion zum Merit-Order Effekt der erneuerbaren Energien', EWI Working Paper. Köln (EWI Working Paper), 07/3(September), p. EWI Working Paper; Nr. 07/3. Available at: https://core.ac.uk/download/pdf/6318641.pdf (Accessed: 12 April 2018). 


\section{Appendix A: Paper 1}

Anke, C. How Renewable Energy Is Changing the German Energy System-a Counterfactual Approach. Z Energiewirtsch 43, 85-100 (2019). https://doi.org/10.1007/s12398-019-00253-w 


\section{Appendix B: Paper 2}

Anke, C.-P.; Schönheit, D.; Möst, D.; Measuring the Impact of Renewable Energy Sources on Power 5Sector Carbon Emissions in Germany-a Methodological Inquiry. Z Energiewirtsch 43, 1-23 (2021). https://doi.org/10.1007/s12398-020-00292-8

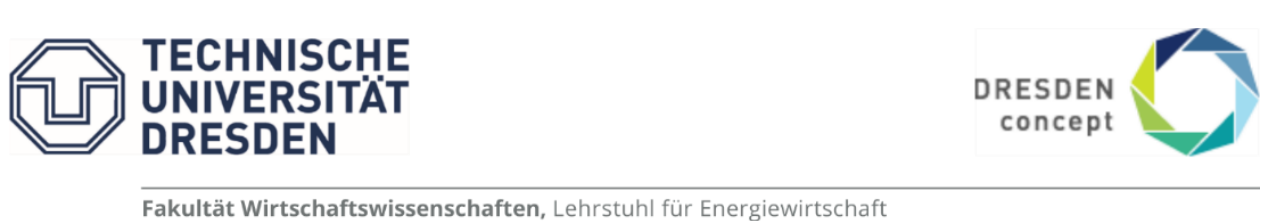

Technische Universität Dresden, 01062 Dresden

Lehrstuhl für Energiewirtschaft

Prof. Dr. Dominik Möst

Münchner Platz 3,

01069 Dresden

Lehrstuhlinhaber

Kontakt: $\quad$ Linda Schwabe

phone: $\quad+4935146333297$

fax: $\quad+4935146339763$

e-mail: $\quad$ ee2@mailbox.tu-dresden.de

\section{ERKLÄRUNG AUTORENSCHAFT}

Am folgenden Beitrag:

"Calculating the impact of German renewable energy source on the carbon emissions - a method comparison"

haben folgende Personen:

$\begin{array}{ll}\text { Autor 1: } & \text { Carl-Philipp Anke (CPA) } \\ \text { Autor 2: } & \text { David Schönheit (DS) } \\ \text { Autor 3: } & \text { Dominik Möst (DM) }\end{array}$

die Autorenschaft. Die Reihenfolge der Autoren richtet sich dabei nach den anteiligen Beiträgen. Die Beiträge der einzelnen Autoren, die die Veröffentlichung verantwortlich mittragen, gliedern sich nach den Kriterien der DFG (2013) zur guten wissenschaftlichen Praxis dabei wie folgt:

- Konzeption der Studie:

- Erarbeitung der Daten:

CPA, DM

- Entwicklung des Modellierungsansatz:

CPA, DS

- Interpretation der Ergebnisse:

CPA, DS

- Formulierung des Manuskripts:

CPA, DS, DM

Die Autoren stimmen mit Ihrer Unterschrift unter diesem Dokument einer Veröffentlichung des Beitrages sowie einer Nutzung des Beitrages zur wissenschaftlichen Qualifikation im Rahmen des Promotionsvorhabens durch andere Autoren zu.

Dresden, 25. September 2020

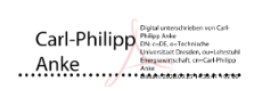

Autor 1

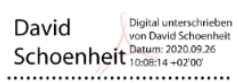

Autor 2

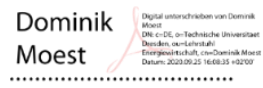

Autor 3 


\section{Appendix C: Paper 3}

Anke, C.-P.; Hobbie, H.; Schreiber, S.; Möst, D.: Coal phase-outs and carbon prices: Interactions between EU emission trading and national carbon mitigation policies; 2020; Energy Policy; 144; https://doi.org/10.1016/j.enpol.2020.111647

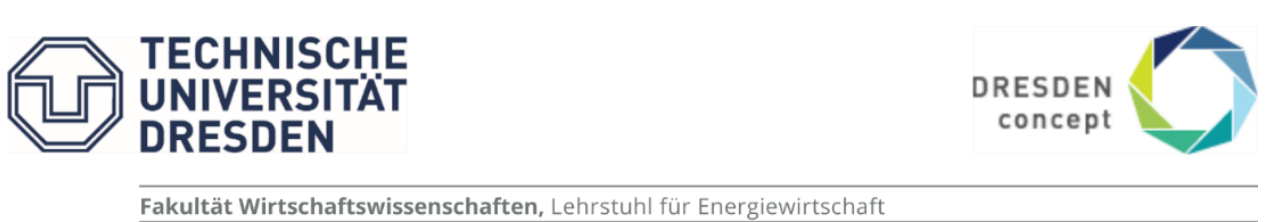

Technische Universität Dresden, 01062 Dresden

Lehrstuhl für Energiewirtschaft

Prof. Dr. Dominik Möst

Münchner Platz 3

01069 Dresden

Lehrstuhlinhaber

Kontakt: $\quad$ Linda Schwabe

phone: $\quad+4935146333297$

fax: $\quad+4935146339763$

e-mail: ee2@mailbox.tu-dresden.de

\section{ERKLÄRUNG AUTORENSCHAFT}

Am folgenden Beitrag:

Coal Phase-outs and Carbon Prices: Interactions between EU Emission Trading and National Carbon Mitigation Policies

haben folgende Personen:

$\begin{array}{ll}\text { Autor 1: } & \text { Carl-Philipp Anke (CPA) } \\ \text { Autor 2: } & \text { Hannes Hobbie (HH) } \\ \text { Autor 3: } & \text { Steffi Schreiber (SSch) } \\ \text { Autor 4: } & \text { Dominik Möst (DM) }\end{array}$

die Autorenschaft. Die Reihenfolge der Autoren richtet sich dabei nach den anteiligen Beiträgen. Die Beiträge der einzelnen Autoren, die die Veröffentlichung verantwortlich mittragen, gliedern sich nach den Kriterien der DFG (2013) zur guten wissenschaftlichen Praxis dabei wie folgt:

- Konzeption der Studie:

$\mathrm{CPA}, \mathrm{HH}, \mathrm{SSCh}$,

- Erarbeitung der Daten:

- Entwicklung des Modellierungsansatz:

- Interpretation der Ergebnisse:

$\mathrm{CPA}, \mathrm{HH}, \mathrm{SSCh}$

$\mathrm{CPA}, \mathrm{HH}$

- Formulierung des Manuskripts:

CPA, $\mathrm{HH}, \mathrm{DM}$

CPA, HH, SSCh,

DM

Die Autoren stimmen mit Ihrer Unterschrift unter diesem Dokument einer Veröffentlichung des Beitrages sowie einer Nutzung des Beitrages zur wissenschaftlichen Qualifikation im Rahmen des Promotionsvorhabens durch andere Autoren zu.

Dresden, 23. April 2020

Carl-Philipp
Anke
Auto............................
Postodresse (Briefe)
TU Dresden,
01062 Dresden
Postadresse (Pakete u.a.).
TU Dresden,
Helmholtzstraße 10,
01069 Dresden
Internet https://tu-dresden.de
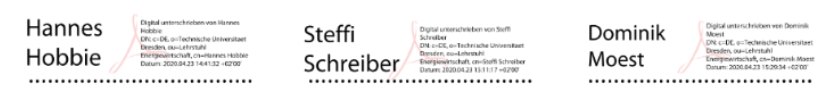

$$
\text { Autor } 2
$$

Autor 3

Besucheradresse
Münchner Platz 2-3

01187 Dresden

\&. Zufahrt für

Rampe Seiteneingang
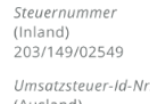

Umsotzsteuer-1d
(Ausland)

(Ausland)
DE 188369991

Kein Zugang für elektronisch signierte sowie verschlüsselte elektronische Dokumente.

Autor 4

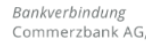




\section{Appendix D: Paper 4}

Breitenstein, M.; Anke, C.-P.; Nguyen, D. K.; Walther, T.; Stranded Asset Risk and Political Uncertainty: The Impact of the Coal Phase-out on the German Coal Industry. Energy Journal 43 (5) (2021). https://doi.org/10.5547/01956574.43.5.mbre

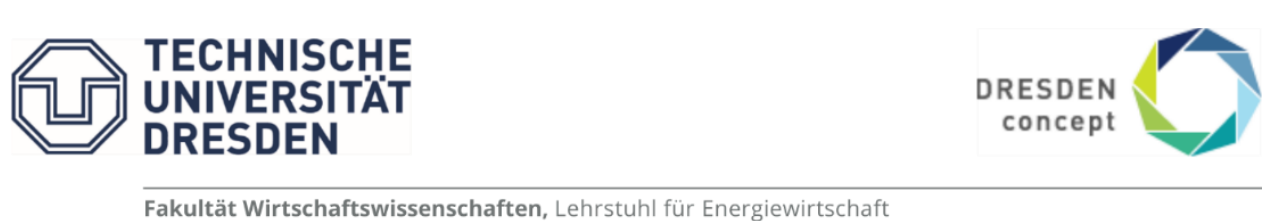

Technische Universität Dresden, 01062 Dresden

Lehrstuhl für Energiewirtschaft

Prof. Dr. Dominik Möst

Münchner Platz 3

01069 Dresden

Lehrstuhlinhaber

Kontakt: $\quad$ Linda Schwabe

phone: $\quad+4935146333297$

fax: $\quad+4935146339763$

e-mail: $\quad$ ee2@mailbox.tu-dresden.de

\section{ERKLÄRUNG AUTORENSCHAFT}

Am folgenden Beitrag:

Stranded Asset Riskand Political Uncertainty: The Impact of the Coal Phase-out on the GermanCoal Industry

haben folgende Personen:

$\begin{array}{ll}\text { Autor 1: } & \text { Miriam Breitenstein (MB) } \\ \text { Autor 2: } & \text { Carl-Philipp Anke (CPA) } \\ \text { Autor 3: } & \text { Duc K. Nguyen (DKN) } \\ \text { Autor 4: } & \text { Thomas Walther (TW) }\end{array}$

die Autorenschaft. Die Beiträge der einzelnen Autoren, die die Veröffentlichung verantwortlich mittragen, gliedern sich nach den Kriterien der DFG (2013) zur guten wissenschaftlichen Praxis dabei wie folgt:

- Konzeption der Studie:

- Erarbeitung der Daten:

- Analyse der Daten:

- Interpretation der Ergebnisse:

- Formulierung des Manuskripts:

MB, CPA, TW
MB
MB, CPA, TW
MB, CPA, TW
$M B, C P A, D K N, T W$

Die Autoren stimmen mit Ihrer Unterschrift unter diesem Dokument einer Veröffentlichung des Beitrages sowie einer Nutzung des Beitrages zur wissenschaftlichen Qualifikation im Rahmen des Promotionsvorhabens durch andere Autoren zu.

Dresden, 09. Juni 2020
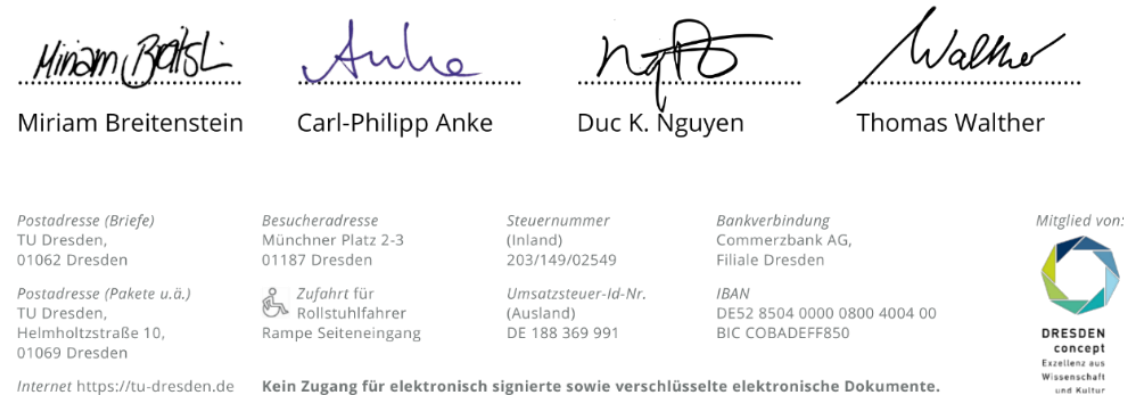


\section{Appendix E: Paper 5}

Anke, C.-P.; Möst, D.; The expansion of RES and the EU ETS - valuable addition or conflicting instruments?, 2021, Energy Policy, 145, https://doi.org/10.1016/j.enpol.2020.112125

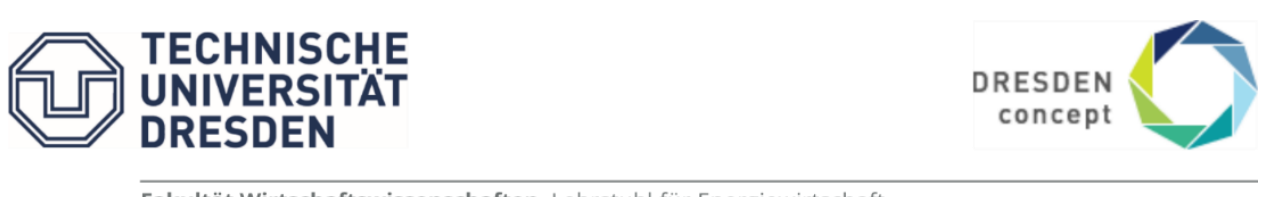

Fakultät Wirtschaftswissenschaften, Lehrstuhl für Energiewirtschaft

Technische Universität Dresden, 01062 Dresden

Lehrstuhl für Energiewirtschaft

Prof. Dr. Dominik Möst

Münchner Platz 3,

01069 Dresden

Lehrstuhlinhaber

$\begin{array}{ll}\text { Kontakt: } & \text { Linda Schwabe } \\ \text { phone: } & +4935146333297 \\ \text { fax: } & +4935146339763 \\ \text { e-mail: } & \text { ee2@mailbox.tu-dresden.de }\end{array}$

\section{ERKLÄRUNG AUTORENSCHAFT}

Am folgenden Beitrag:

The expansion of RES and the EU ETS -valuable addition or conflicting instruments?

haben folgende Personen: Autor 1: Carl-Philipp Anke (CPA)

Autor 2: $\quad$ Dominik Möst (DM)

die Autorenschaft. Die Reihenfolge der Autoren richtet sich dabei nach den anteiligen Beiträgen. Die Beiträge der einzelnen Autoren, die die Veröffentlichung verantwortlich mittragen, gliedern sich nach den Kriterien der DFG (2013) zur guten wissenschaftlichen Praxis dabei wie folgt:

- Konzeption der Studie:

- Erarbeitung der Daten:

CPA, DM

- Entwicklung des Modellierungsansatz:

CPA

- Interpretation der Ergebnisse:

CPA

- Formulierung des Manuskripts:

CPA, DM

CPA, DM

Die Autoren stimmen mit Ihrer Unterschrift unter diesem Dokument einer Veröffentlichung des Beitrages sowie einer Nutzung des Beitrages zur wissenschaftlichen Qualifikation im Rahmen des Promotionsvorhabens durch andere Autoren zu.

Dresden, 15. Juni 2020

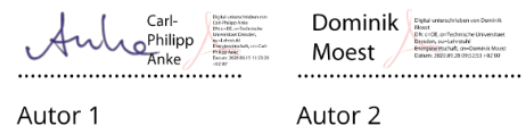

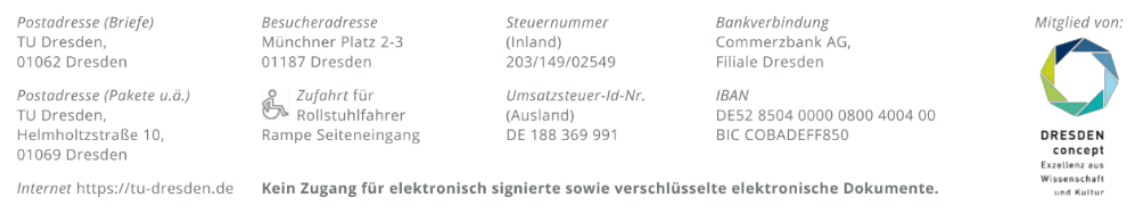




\section{Schriften des Lehrstuhls für Energiewirtschaft, TU Dresden}

Technische Universität Dresden

Fakultät Wirtschaftswissenschaften

Lehrstuhl für Energiewirtschaft

In der Schriftenreihe sind auf Qucosa $囚$, dem sächsischen Dokumenten- und Publikationsserver, bisher erschienen:

Band 1 Managing Congestion and Intermittent Renewable Generation in Liberalized Electricity Markets

(Friedrich Kunz)

http://nbn-resolving.de/urn:nbn:de:bsz:14-qucosa-108793

Band 2 Der Stromausfall in München - Einfluss auf Zahlungsbereitschaften für Versorgungssicherheit und auf die Akzeptanz Erneuerbarer Energien

(Daniel K. J. Schubert, Thomas Meyer, Alexander von Selasinsky, Adriane Schmidt, Sebastian Thuß, Niels Erdmann und Mark Erndt)

http://nbn-resolving.de/urn:nbn:de:bsz:14-qucosa-117777

Band 3 Abschätzung der Entwicklung der Netznutzungsentgelte in Deutschland (Fabian Hinz, Daniel Iglhaut, Tobias Frevel, Dominik Möst) http://nbn-resolving.de/urn:nbn:de:bsz:14-qucosa-141381

Band 4 Potenziale der Elektrizitätserzeugung aus erneuerbaren Ressourcen im Freistaat Sachsen

(Hannes Hobbie, Vera Schippers, Michael Zipf, Dominik Möst)

http://nbn-resolving.de/urn:nbn:de:bsz:14-qucosa-153350

Band 5 Energiewende Sachsen - Aktuelle Herausforderungen und Lösungsansätze Beiträge der Abschlusskonferenz des ENERSAX-Projektes

(Dominik Möst und Peter Schegner (Hrsg.)) http://nbn-resolving.de/urn:nbn:de:bsz:14-qucosa-156464

Band 6 Electricity transmission line planning: Success factors for transmission system operators to reduce public opposition

(Stefan Perras)

http://nbn-resolving.de/urn:nbn:de:bsz:14-qucosa-161770

Band 7 Renewable energy in North Africa: Modeling of future electricity scenarios and the impact on manufacturing and employment (Christoph Philipp Kost) http://nbn-resolving.de/urn:nbn:de:bsz:14-qucosa-176538

Band 8 Kurzgutachten zur regionalen Ungleichverteilung der Netznutzungsentgelte (Dominik Möst, Fabian Hinz, Matthew Schmidt, Christoph Zöphel)

http://nbn-resolving.de/urn:nbn:de:bsz:14-qucosa-184452

Band 9 The integration of renewable energy sources in continuous intraday markets for electricity

(Alexander von Selasinsky)

http://nbn-resolving.de/urn:nbn:de:bsz:14-qucosa-202130

Band 10 Bewertung von Szenarien für Energiesysteme

(Daniel K. J. Schubert)

http://nbn-resolving.de/urn:nbn:de:bsz:14-qucosa-202226

Band 11 Deutschland, ein Solarmärchen? Die Zweite Phase der Energiewende zwischen Richtungsstreit und Systemintegration

(Sebastian Thuß)

http://nbn-resolving.de/urn:nbn:de:bsz:14-qucosa-231486 
Band 12 Voltage Stability and Reactive Power Provision in a Decentralizing Energy System - A Techno-economic Analysis

(Fabian Hinz)

http://nbn-resolving.de/urn:nbn:de:bsz:14-qucosa-229585

Band 13 Electricity, Heat, and Gas Sector Data for Modeling the German System

(Friedrich Kunz, Mario Kendziorski, Wolf-Peter Schill, Jens Weibezahn, Jan Zepter, Christian von Hirschhausen, Philipp Hauser, Matthias Zech, Dominik Möst,

Sina Heidari, Björn Felten, Christoph Weber)

http://nbn-resolving.de/urn:nbn:de:bsz:14-qucosa-233511

Band 14 Demand Side Management in Deutschland zur Systemintegration erneuerbarer Energien

(Theresa Ladwig)

http://nbn-resolving.de/urn:nbn:de:bsz:14-qucosa-236074

Band 15 Modellgestützte Wirtschaftlichkeitsbewertung von Betriebskonzepten für Elektrolyseure in einem Energiesystem mit hohen Anteilen erneuerbarer Energien

(Julia Michaelis)

http://nbn-resolving.de/urn:nbn:de:bsz:14-qucosa-235773

Band 16 Begleitstudie WindNODE - Lastverschiebepotentiale in Dresden (Carl-Philipp Anke, Constantin Dierstein, Dirk Hladik, Dominik Möst) http://nbn-resolving.de/urn:nbn:de:bsz:14-qucosa2-312491

Band 17 Einflussfaktoren auf das Übertragungsnetz im Jahr 2030 für Deutschland Eine techno-ökonomische Analyse der Wechselwirkungen auf den Umfang des Netzausbaus, die Systemkosten und die Integration erneuerbarer Energien (David Gunkel) https://nbn-resolving.org/urn:nbn:de:bsz:14-qucosa2-716026

Band 18 Auswirkungen der Kopplung von Strom- und Wärmemarkt auf die künftige Integration der erneuerbaren Energien und die CO2-Emissionen in Deutschland (Gerda Deac) https://nbn-resolving.org/urn:nbn:de:bsz:14-qucosa2-725153

Band 19 Fristigkeit und Politik. Konzeptualisierung und Analyse von langfristigkeitsfördernden Institutionen im Kontext energiepolitischer Steuerung (Nick Pruditsch) https://nbn-resolving.org/urn:nbn:de:bsz:14-qucosa2-748650

Band 20 Economics of Ancillary Services for Electricity - Managing Uncertain Power Generation and Grid Operation in the Distribution Network (Michael Zipf) https://nbn-resolving.org/urn:nbn:de:bsz:14-qucosa2-751856

Band 21 Short- and mid-term uncertainties affecting the trade and transmission of electricity with a focus on flow-based market coupling (David Josua Schönheit) https://nbn-resolving.org/urn:nbn:de:bsz:14-qucosa2-751888

Band 22 Quantitative Analysis of the Reduction of Greenhouse Gas Emissions in the Power Sector (Carl-Philipp Anke) https://nbn-resolving.org/urn:nbn:de:bsz:14-qucosa2-761374 


\section{Kurzzusammenfassung}

Die kumulative Dissertation adressiert in fünf wissenschaftlichen Artikeln zentrale Fragen der Klimaschutzpolitik zur Vermeidung von Treibhausgasemissionen im europäischen Stromsektor. Der Fokus liegt dabei insbesondere auf den Wechselwirkungen zwischen nationalen Maßnahmen (Ausbau erneuerbarer Energie oder Kohleausstieg) und europäischen Maßnahmen (Europäischer Emissionshandel). Die ersten beiden Papiere entwickeln eine Methodik zur Berechnung der vermiedenen Treibhausgasemissionen erneuerbarer Energien. Die nächsten beiden Papiere fokussieren sich auf die Auswirkungen des Kohleausstiegs auf den Europäischen Emissionshandel sowie die Werthaltigkeit der betroffenen Unternehmen. Das fünfte und letzte Papier untersucht, welche Wechselwirkungen verschiedene Ausbauszenarien erneuerbarer Energien auf den Emissionshandel haben und wie sich deren Wirtschaftlichkeit ändert. Die Arbeiten basieren alle auf fundamentalen Strommarktmodellen und zeigen zusammenfassend auf, dass eine größere Integration der unterschiedlichen Klimaschutzmaßnahmen notwendig ist, um die Transformation des Stromsektors ökonomisch effizient zu gestalten.

\section{Autor}

Carl-Philipp Anke absolvierte sein Studium des Wirtschaftsingenieurwesens an der TU Bergakademie Freiberg, der Luleå University of Technology sowie dem Karlsruher Institut für Technologie (KIT). 2015 erlangte er den Master of Science. Im Anschluss war Carl-Philipp Anke für die Managementberatungen EY und Roland Berger tätig, wobei sein Fokus auf dem Energiesektor lag. Von 2018 bis 2021 war er wissenschaftlicher Mitarbeiter am Lehrstuhl für Energiewirtschaft der TU Dresden und in diversen nationalen und internationalen Forschungsprojekten involviert. 